\title{
TRPA1 Channels Mediate Cold Temperature Sensing in Mammalian Vagal Sensory Neurons: Pharmacological and Genetic Evidence
}

\author{
Otto Fajardo, Victor Meseguer, Carlos Belmonte, and Félix Viana \\ Instituto de Neurociencias de Alicante, Universidad Miguel Hernández-Consejo Superior de Investigaciones Científicas, 03550 San Juan de Alicante, Spain
}

Cold thermoreceptors have been described in different territories of the vagus nerve. Application of cold temperature to these visceral afferents can evoke major protective reflexes and thermoregulatory responses. However, virtually nothing is known about the transduction mechanisms underlying cold sensitivity in vagal afferents. Here, we investigated the effects of cold stimulation on intracellular calcium responses and excitability of cultured vagal sensory neurons in the rat nodose ganglion. A large fraction of vagal neurons were activated by cold, with a mean threshold of $\sim 24^{\circ} \mathrm{C}$. Cooling was accompanied by development of a small inward current and the firing of action potentials. Most cold-sensitive neurons were also activated by heat and capsaicin, suggesting a nociceptive function. The pharmacological response to TRPM8 and TRPA1 agonists and antagonists suggested that, unlike results observed in somatic tissues, TRPA1 is the major mediator of cold-evoked responses in vagal visceral neurons. Thus, most cold-evoked responses were potentiated by cinnamaldehyde, menthol, icilin, and BCTC [4-(3-chloro-pyridin-2-yl)-piperazine-1-carboxylic acid (4-tert-butyl-phenyl)-amide], agonists of TRPA1, and were inhibited by ruthenium red, camphor, and HC03001 [2-(1,3-dimethyl-2,6-dioxo-1,2,3,6-tetrahydro-7H-purin-7-yl)- $N$ (4-isopropylphenyl)acetamide]. Results in mouse nodose neurons revealed a similar pharmacological profile of cold-evoked responses. Furthermore, experiments in TRPA1 knock-out mice showed a large reduction in the percentage of cold-sensitive neurons compared with wild-type animals. Together, these results support an important role of TRPA1 channels in visceral thermosensation and indicate major differences in the transduction of temperature signals between somatic and visceral sensory neurons.

Key words: thermotransduction; nodose ganglion; laryngeal afferents; TRP channel; nociceptor; noxious cold

\section{Introduction}

The thoracic and abdominal viscera are innervated by two sets of afferent fibers: vagal afferents projecting to the nodose and jugular ganglia, and spinal afferents projecting to the dorsal root ganglia (DRGs). Spinal afferents are primarily involved in nociception, evoking conscious sensations of discomfort and pain (Cervero, 1994). In contrast, many vagal afferents do not evoke conscious sensations but can trigger powerful regulatory reflexes that are critical for visceral homeostasis (Paintal, 1973). Most vagal axons are unmyelinated, conducting action potentials in the C-fiber range (Mei et al., 1980; Li and Schild, 2002; Bielefeldt

\footnotetext{
Received April 18, 2008; revised June 6, 2008; accepted June 25, 2008.

This work was supported by Spanish Ministry of Education and Science Project Grants BFU2007-61855 (F.V.) and BFU2005-08741 (C.B.), and Consolider-Ingenio 2010 Grant CSD2007-00023 (C.B.). 0.F. and V.M were supported by predoctoral fellowships from the Spanish Consejo Superior de Investigaciones Científicas and the Generalitat Valenciana. We thank Eva Quintero, Ana Miralles, and Sophie Sarret for excellent technical assistance and Stuart Ingham for help with illustrations. We thank Dr. Roberto Gallego for comments and continuous support. We thank Dr. Hanna Jostock (Grünenthal) for the gift of BCTC and Dr. Magdalene Moran (Hydra Biosciences) for the gift of HC03001. The HEK293 cell line expressing rat TRPM8 and the inducible CHO cell line stably expressing mouse TRPA1 channels were kind gifts of Dr. Ramón Latorre (Centro de Estudios Cientificos, Valdivia, Chile) and Dr. Ardem Patapoutian (The Scripps Research Institute, La Jolla, CA), respectively. The mouse TRPA1 (-/-) line was generated by Dr. Kevin Kwan and Dr. David Corey (Harvard Medical School) and generously donated with no strings attached.

Correspondence should be addressed to Dr. Félix Viana, Instituto de Neurociencias de Alicante, Universidad Miguel Hernández-Spanish Consejo Superior de Investigaciones Científicas, Avenida S. Ramón y Cajal s.n., Apartado 18, 03550 San Juan de Alicante, Spain. E-mail: felix.viana@umh.es.

DOI:10.1523/JNEUROSCI.1696-08.2008
}

Copyright $\odot 2008$ Society for Neuroscience $\quad 0270-6474 / 08 / 287863-13 \$ 15.00 / 0$ et al., 2006). Vagal afferents are free nerve endings and the majority are polymodal, responding to physical stimuli (mechanical and thermal) and chemical irritants (Higashi, 1986; Carr and Undem, 2003; Lennerz et al., 2007). Activation of these fibers triggers powerful defensive reflexes such as cough, apnea, mucus secretion, and vomit aimed at protecting the organism from the detected insult (Coleridge and Coleridge, 1984; Lee et al., 1992; Lee and Pisarri, 2001).

Warm and cold thermal receptors have been identified in different vagal territories including the gastrointestinal tract (El Ouazzani and Mei, 1982; Lennerz et al., 2007) and the upper and lower respiratory tract (Jammes et al., 1987; Sant'Ambrogio et al., 1988). In the esophagus and stomach, these receptors are well suited for monitoring the temperature of ingested materials. Furthermore, breathing cold air can also trigger protective vagal reflexes, such as cold-induced bronchospasm, cough, and hypoapnea (Jammes et al., 1986; Orani et al., 1991). Visceral thermoreceptors are also thought to play an important role in the regulation of body temperature (Steiner et al., 2007).

The cellular and molecular bases of cold temperature transduction in vagal afferents are currently unknown. In contrast, major advances have taken place in elucidating the mechanisms of cold sensing by somatic primary afferent neurons (for review, see Patapoutian et al., 2003; McKemy, 2005). Transient receptor potential M8 (TRPM8), a nonselective cation channel activated 
by moderate cold and cooling compounds such as menthol and icilin (McKemy et al., 2002; Peier et al., 2002), is the main candidate for transducing innocuous cold temperatures in trigeminal and DRG neurons (for review, see Reid, 2005). TRPA1 is another TRP channel activated by lower temperatures (threshold, $\sim 18^{\circ} \mathrm{C}$ ) and a plethora of chemical compounds, including mustard oil and many environmental irritants (Story et al., 2003; Bautista et al., 2005). These two channels are expressed in essentially nonoverlapping subsets of sensory neurons (Story et al., 2003). However, the role of TRPA1 in noxious cold sensing is currently disputed. In some studies, recombinant TRPA1 studies were activated by cold (Story et al., 2003), although other laboratories failed to replicate these results (Nagata et al., 2005; Bautista et al., 2006). Characterization of two different lines of TRPA1(-/-) animals has not settled the issue either: one study found no deficits in cold-evoked responses (Bautista et al., 2006), whereas the other observed only moderate deficits and restricted to females (Kwan et al., 2006). Thus, firm evidence for cold activation of TRPA1 channels in native sensory neurons is currently lacking.

Nodose sensory neurons express many thermosensitive TRPs (thermoTRPs), including TRPV1, TRPM8, and TRPA1 (Zhang et al., 2004; Bielefeldt et al., 2006; Ni et al., 2006; Peeters et al., 2006). Using calcium fluorimetry, Zhang et al. (2004) reported cold-evoked responses in a small fraction of mice nodose neurons but the possible underlying mechanisms was not addressed (Zhang et al., 2004). Another recent study demonstrated the presence of TRPA1 in nodose ganglia and cinnamaldehyde (CM) responses on cultured nodose ganglia and pulmonary fibers (Nassenstein et al., 2008).

Here, we report the effects of cooling stimuli on cultured rat nodose neurons. We found a large population of cells activated by cooling stimuli. Cooling was accompanied by development of a small inward current and firing of action potentials. The pharmacological profile of cold-sensitive neurons, using agonists of thermoTRPs, revealed that the majority harbor TRPA1 and TRPV1 channels, suggesting that they are involved in nociceptive responses. Furthermore, specific TRPA1 antagonists abrogated most cold-evoked responses. Cold responses were also greatly diminished in TRPA1 knock-out mice. Together, the pharmacological and genetic evidence indicates that TRPA1 is the major contributor to cold sensing in vagal afferent fibers.

\section{Materials and Methods}

Animals. All experimental procedures concerning the use of animals were performed according to the Spanish Royal Decree 223/1988 and the European Community Council directive 86/609/EEC. A total of 39 adults male Sprague Dawley rats $(200-400 \mathrm{~g})$ and 15 adult male mice were used. TRPA1 knock-out mice were kindly provided by Dr. D. Corey (Harvard Medical School, Boston, MA) (Kwan et al., 2006). These mice were mated with C57BL/6 wild-type mice and the offspring were crossed to obtain the TRPA1 $(+/+)(n=6)$ and TRPA1 $(-/-)(n=9)$ mice used in this study.

Retrograde labeling of laryngeal nerve terminals. Animals were anesthetized with isofluorane. A ventral midline incision was made at neck level to gain access to the larynx. A small volume $(\sim 8 \mu \mathrm{l})$ of DiI $(50 \mathrm{mg} / \mathrm{ml}$ in DMSO) was injected with a Hamilton syringe at multiple sites beneath the laryngeal mucosa. Nine to $12 \mathrm{~d}$ after injection, the animals were killed with $\mathrm{CO}_{2}$ and the nodose ganglia dissected out and cultured (see below). DiI-labeled neurons were identified by their fluorescence emission when excited with $550 \mathrm{~nm}$ light.

Isolation and culture of nodose and dorsal root ganglia neurons. The nodose ganglion is located bilaterally in the neck, at the level of the bifurcation of the carotid artery. Freshly dissociated nodose ganglia of adult rats were enzymatically dissociated by incubation in a solution containing $155 \mathrm{~mm} \mathrm{NaCl}, 1.5 \mathrm{~mm} \mathrm{~K}_{2} \mathrm{HPO}_{4}, 5.6 \mathrm{~mm}$ HEPES, $4.8 \mathrm{~mm}$ NaHEPES, $5 \mathrm{~mm}$ glucose, $100 \mathrm{U} / \mathrm{ml}$ penicillin, $100 \mu \mathrm{g} / \mathrm{ml}$ streptomycin, 2 $\mathrm{mg} / \mathrm{ml}$ collagenase type XI, and $9 \mathrm{mg} / \mathrm{ml}$ dispase (all from Sigma) in $5 \%$ $\mathrm{CO}_{2}$ for $35 \mathrm{~min}$ at $37^{\circ} \mathrm{C}$. Thereafter, nodose ganglia were mechanically dissociated by passing 5-10 times through a fire-polished glass Pasteur pipette. Individual cells were harvested by centrifugation $(700 \times g$ for 4 $\mathrm{min}$ ) before resuspension in DMEM with $10 \%(\mathrm{v} / \mathrm{v})$ fetal bovine serum (Invitrogen), $100 \mathrm{U} / \mathrm{ml}$ penicillin (Invitrogen), $100 \mu \mathrm{g} / \mathrm{ml}$ streptomycin (Invitrogen), and $20 \mathrm{ng} / \mathrm{ml}$ nerve growth factor (NGF) (Invitrogen). Dorsal root ganglion neurons from adult rats were isolated and cultured with an identical procedure. In some experiments, NGF was omitted from the culture medium.

Culture of mammalian cell lines. Chinese hamster ovary cells (CHO) were cultured in DMEM containing 10\% of fetal bovine serum, $2 \%$ glutamax, $1 \%$ nonessential amino acids (Invitrogen), and $200 \mu \mathrm{g} / \mathrm{ml}$ penicillin/streptomycin. CHO cells stably expressing mouse TRPA1 (Story et al., 2003) were cultured in the same media plus $200 \mu \mathrm{g} / \mathrm{ml}$ hygromicin (Sigma) and $5 \mu \mathrm{g} / \mathrm{ml}$ blasticidin (Invitrogen). Induction of TRPA1 expression was achieved by addition of $0.25-0.5 \mu \mathrm{g} / \mathrm{ml}$ tetracycline $4-18 \mathrm{~h}$ before recording. Human embryonic kidney 293 (HEK293) cells stably expressing rat TRPM8 channels (CR\#1 cells) (Brauchi et al., 2004) were cultured in DMEM containing 10\% of fetal bovine serum, $1 \%$ penicillin/ streptomycin, and $450 \mu \mathrm{g} / \mathrm{ml}$ geneticin (G418).

Calcium imaging. The calcium imaging experiments were conducted with the fluorescent indicator fura-2. Before each experiment, the cells were incubated with $5 \mu \mathrm{M}$ fura-2 $\mathrm{AM}$ (Invitrogen) for $45 \mathrm{~min}$ at $37^{\circ} \mathrm{C}$. Fluorescence measurements were made with a Zeiss Axioskop FS upright microscope fitted with an ORCA-ER CCD camera (Hamamatsu). Fura-2 was excited at 340 and $380 \mathrm{~nm}$ (excitation time 200-300 ms) with a rapid switching monochromator (TILL Photonics), and the emitted fluorescence was filtered with a $510 \mathrm{~nm}$ long-pass filter. Mean fluorescence intensity ratios (F340/F380) were displayed online with Metafluor software (Molecular Devices). The calcium imaging-experiments were performed simultaneously with temperature recordings. The bath solution, from here on referred to as "control solution," contained (in mM) 140 $\mathrm{NaCl}, 3 \mathrm{KCl}, 2.4 \mathrm{CaCl}_{2}, 1.3 \mathrm{MgCl}_{2}, 10 \mathrm{HEPES}$, and 10 glucose, and was adjusted to a $\mathrm{pH}$ of 7.4 with $\mathrm{NaOH}$. In situ calibration of calcium signals involved the incubation of fura-2-loaded cells with $\mathrm{Ca}^{2+}$-free/10 mM EGTA and high $\mathrm{Ca}^{2+}$ solutions $(10 \mathrm{~mm})$ plus the ionophore ionomycin $(2 \mu \mathrm{M})$ to determine the values of $R_{\min }$ and $R_{\max } \cdot\left[\mathrm{Ca}^{2+}\right]_{\mathrm{i}}$ was calculated according to the equation described by Grynkiewicz et al. (1985): $\left[\mathrm{Ca}^{2+}\right]_{\mathrm{i}}=K_{\mathrm{d}} \times F_{\max } / F_{\min } \times\left(R-R_{\min }\right) /\left(R_{\max }-R\right) \cdot R_{\text {min }}$ is the ratio of fluorescence intensities at 340 and $380 \mathrm{~nm}$ obtained at zero $\left[\mathrm{Ca}^{2+}\right]_{\mathrm{i}}, R_{\max }$ is the ratio at saturating $\left[\mathrm{Ca}^{2+}\right]_{\mathrm{i}}, K_{\mathrm{d}}$ is the dissociation constant for fura-2, and $F_{\min }$ and $F_{\max }$ are the fluorescence intensities at $380 \mathrm{~nm}$ in the absence and presence of $\mathrm{Ca}^{2+}$, respectively. The apparent dissociation constant for fura- 2 used in all calibrations was $225 \mathrm{~nm}$ (Grynkiewicz et al., 1985).

Electrophysiology. Perforated-patch voltage-clamp or current-clamp recordings were performed simultaneously with temperature and calcium fluorimetry recordings in nodose neurons. Standard patch pipettes (5-7 M $\Omega$ ) were made of borosilicate glass capillaries (Harvard Apparatus) and contained $105 \mathrm{~mm}$ K gluconate, $35 \mathrm{~mm} \mathrm{KCl}, 10 \mathrm{~mm} \mathrm{NaCl}, 10 \mathrm{~mm}$ HEPES, $0.1 \mathrm{~mm}$ EGTA, and $2 \mathrm{mg} / \mathrm{ml}$ amphotericin $\mathrm{B}$, pH 7.4. Intracellular solution for whole-cell patch-clamp recording of HEK293-TRPM8 cells contained (in mM) $140 \mathrm{CsCl}, 0.6 \mathrm{MgCl}_{2}, 1$ EGTA, 10 HEPES, 1 $\mathrm{ATPNa}_{2}$, and $0.1 \mathrm{GTPNa}(280 \mathrm{mOsm} / \mathrm{kg}, \mathrm{pH} 7.4$, adjusted with $\mathrm{CsOH})$. For recordings of CHO-TRPAl cells, it contained (in mM) $140 \mathrm{NaCl}, 5$ $\mathrm{CsCl}, 10 \mathrm{EGTA}$, and $10 \mathrm{HEPES}$ (305 mOsm $/ \mathrm{kg}, \mathrm{pH} 7.4$, adjusted with $\mathrm{NaOH}$ ). Current or voltage signals were recorded with an EPC8 patchclamp amplifier (HEKA Electronics). Stimulus delivery and data acquisition were performed using pClamp 9 software (Molecular Devices). Current development was monitored with repetitive $(0.2 \mathrm{~Hz})$ injections of 1-s-duration voltage ramps from -100 to $+100 \mathrm{mV}$. Electrophysiological data were analyzed with WinASCD written by Dr. Guy Droogmans (Katholieke Universiteit Leuven, Leuven, Belgium) (ftp://ftp.cc.kuleuven.ac.be/pub/droogmans/winascd.zip) and Origin 7.0 (OriginLab).

Temperature stimulation. Coverslip pieces with cultured cells were 
A

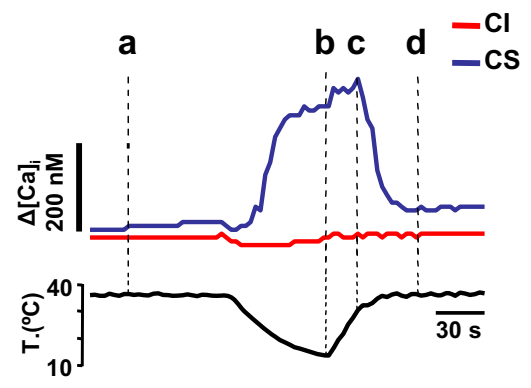

D

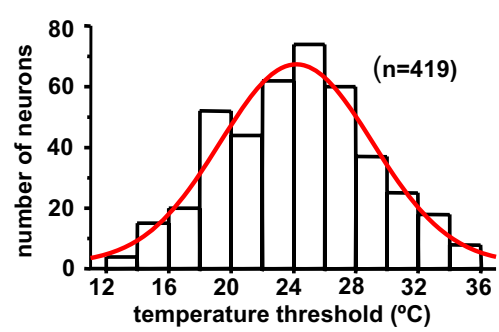

B

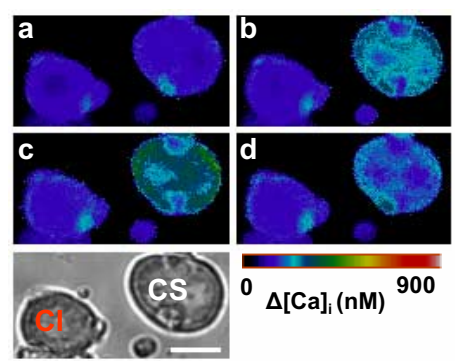

E

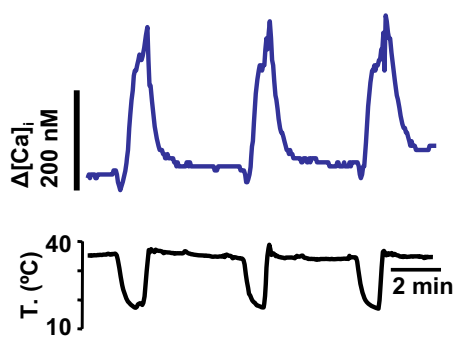

C
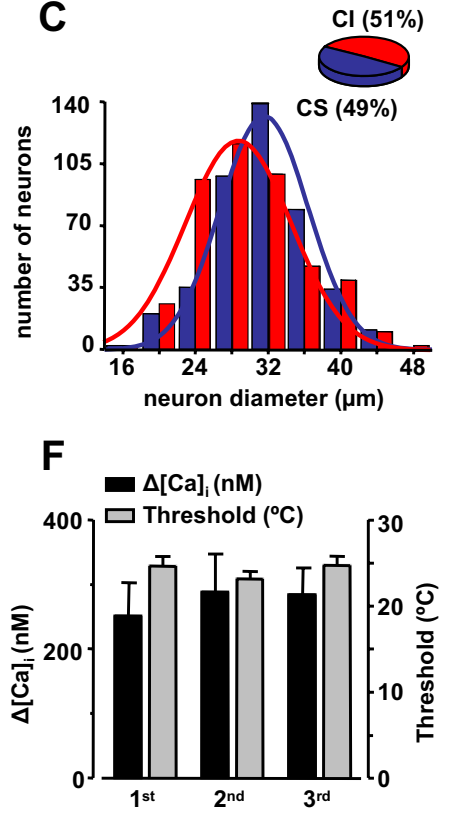

Figure 1. Characterization of CS and CI neurons in the nodose ganglion. $A$, Simultaneous recording of $\left[\mathrm{Ca}^{2+}\right]_{\mathrm{i}}$ (top trace) and bath temperature (bottom trace) during application of a cooling ramp to a cold-sensitive $C S$ nodose neuron (blue trace). Note the slowly developing $C^{2+}{ }^{2+}$ response that peaks (line $c$ ) during the rewarming phase. In the same optical field, a second neuron (red trace) did not show a $\left[\mathrm{Ca}^{2+}\right]_{\mathrm{i}}$ response to cooling (CI). $\boldsymbol{B}$, Transmitted and pseudocolor ratiometric fluorescent calcium images (fura-2) of the two neurons displayed in $\boldsymbol{A}$ at times marked by vertical dotted lines. $\boldsymbol{C}$, Histogram showing the distribution of cell diameters for $\mathrm{CS}$ and $\mathrm{Cl}$ neurons sampled randomly in cultures of adult rat nodose ganglia. The continuous lines are Gaussian fits to the data. The inset shows a pie chart with the percentage of $\mathrm{CS}$ and $\mathrm{Cl}$ neurons. $\boldsymbol{D}$, Histogram showing the distribution of temperature thresholds in nodose neurons, detected by $\left[\mathrm{Ca}^{2+}\right]_{\mathrm{i}}$ elevations during cooling ramps. The red trace is a Gaussian fit to the data (center, 24.0; width, 10.7). $\boldsymbol{E}$, Response of a (S neuron to three consecutive applications of a cooling pulse. $\boldsymbol{F}$, Histogram showing the average $\left[\mathrm{Ca}^{2+}\right]_{\mathrm{i}}$ response (black) and the average thermal threshold (gray) to three consecutive cooling pulses $(n=14)$.

placed in a microchamber and continuously perfused with solutions warmed at $34-36^{\circ} \mathrm{C}$. The temperature was adjusted with a water-cooled Peltier device placed at the inlet of the chamber, and controlled by a feedback device. Cold sensitivity was investigated with a temperature drop to $\sim 12^{\circ} \mathrm{C}$.

Experimental protocols and interpretation of results. During calcium imaging and electrophysiological experiments, the effects of agonist or antagonist compounds were investigated with a protocol, wherein a first cooling stimulus in control solution was followed by a second one in the presence of the agent. At the end of the protocol, a solution containing elevated $\mathrm{K}^{+}(30 \mathrm{~mm})$ was perfused to test the viability of the cells. Only cells showing a calcium increase to $30 \mathrm{~mm} \mathrm{KCl}$ were included in the analysis.

Chemical modulators. Camphor (Sigma), thapsigargin (Alomone), nifedipine (RBI), l-menthol (Scharlau), ruthenium red (RR; Sigma), cinnamaldehyde (Sigma), 2-(1,3-dimethyl-2,6-dioxo-1,2,3,6-tetrahydro$7 \mathrm{H}$-purin-7-yl)- $\mathrm{N}$-(4-isopropylphenyl)acetamide (HC03001) (Hydra Biosciences), and 4-(3-chloro-pyridin-2-yl)-piperazine-1-carboxylic acid (4-tert-butyl-phenyl)-amide (BCTC; Grünenthal) were stored as stock solutions and diluted immediately before the experiments.

Data analysis. Data are reported as mean \pm SEM. The threshold temperatures were estimated as the first point at which the measured signal (F340/F380 or current) deviated by at least four times the SD of its baseline. When comparing two means, statistical significance $(p<0.05)$ was assessed by Student's two-tailed $t$ test. When comparing more than two means, statistical significance was assessed by one-way ANOVA. When comparing proportions, statistical significance was assessed by the $\chi^{2}$ test. In graphs, ${ }^{\star} p<0.05,{ }^{\star *} p<0.01$, and ${ }^{\star * *} p<0.001$.

\section{Results}

Cold-evoked $\left[\mathrm{Ca}^{2+}\right]_{\mathrm{i}}$ responses in cultured rat nodose ganglion neurons

Cold sensitivity was explored in cultured rat nodose neurons loaded with the calcium-sensitive dye fura-2. When the bath temperature was lowered from a base value of $34-36^{\circ} \mathrm{C}$ to $\sim 12^{\circ} \mathrm{C}$, a large fraction of nodose neurons responded with an elevation in their $\left[\mathrm{Ca}^{2+}\right]_{\mathrm{i}}$ (Fig. $1 A, B$ ). In 91 fields monitored randomly, 419 of 857 cells $(49 \%)$ were cold-sensitive. Figure $1 C$ shows the distribution of cell diameters among cold-sensitive (CS) and coldinsensitive (CI) neurons. In contrast to results obtained previously in trigeminal ganglion and DRG neurons (McKemy et al., 2002; Reid et al., 2002; Viana et al., 2002; Thut et al., 2003), CS neurons were larger than CI neurons (31.5 vs $29.8 \mu \mathrm{m} ; p<$ $0.001) .\left[\mathrm{Ca}^{2+}\right]_{\mathrm{i}}$ responses in individual cells had a variable time course and amplitude. Most were slow rising, augmenting monotonically with the decline in temperature and often peaking on the rewarming phase (Fig. $1 A$ ). The mean $\left[\mathrm{Ca}^{2+}\right]_{\mathrm{i}}$ elevation was $165 \pm 7 \mathrm{nM}(n=419)$. The temperature threshold distribution covered the full range of temperatures tested $\left(35-12^{\circ} \mathrm{C}\right)$ and had a mean value of $24 \pm 0.2^{\circ} \mathrm{C}($ Fig. $1 \mathrm{D}), \sim 4^{\circ} \mathrm{C}$ below that of trigeminal or DRG CS neurons (Reid et al., 2002; Viana et al., 2002).

Next, we tested the stability of the response to repeated thermal stimuli (Fig. $1 E$ ). After application of three cooling ramps at 4 min intervals ( $n=14$ neurons), the amplitude of the second and third response was found to be of the same magnitude as the first one (one-way ANOVA, $p=0.86$ ) (Fig. $1 F$ ). Thermal threshold of individual neurons did not change significantly either (Fig. $1 F$ ). Altogether, these results indicate the absence of significant adaptation or sensitization of the cold-evoked response during brief cooling applications.

We were surprised by the high percentage of cold-evoked responses observed in nodose neurons, much higher than in similar studies performed on trigeminal ganglion and DRG neurons (Reid et al., 2002; Viana et al., 2002; Thut et al., 2003). Because NGF is known to upregulate the number of CS neurons (Babes et al., 2004), and our cultures were supplemented routinely with NGF, we examined the possible influence of this growth factor on 
A

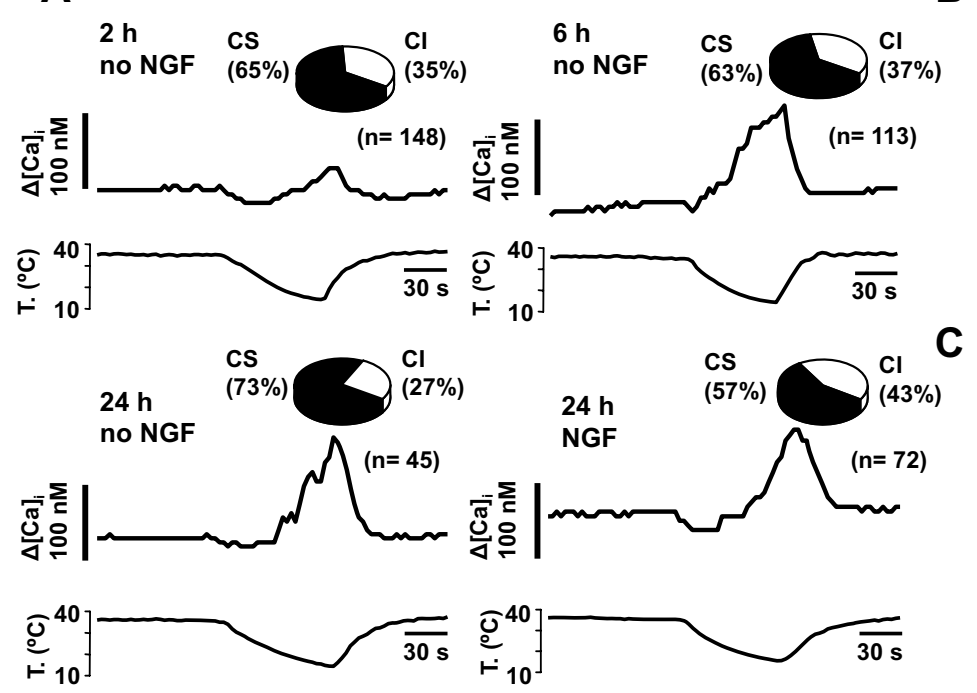

B
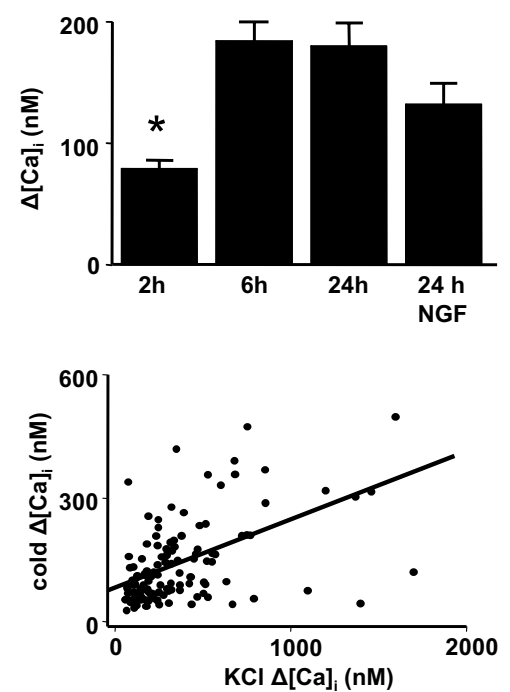

Figure 2. NGF does not affect cold sensitivity of nodose ganglion neurons. $\boldsymbol{A}$, Simultaneous recording of $\left[\mathrm{Ca}^{2+}\right]_{\mathrm{i}}$ (top trace) and bath temperature (bottom trace) during application of a cooling ramp in four representative examples of cultured nodose neurons under different experimental conditions. Insets, Pie charts with the percentage of $C S$ and $C$ I neurons under each condition. $\boldsymbol{B}$, Mean $\left[\mathrm{Ca}^{2+}\right]_{\mathrm{i}}$ elevation during cooling in acutely cultured $(2,6$, and $24 \mathrm{~h}$ without NGF and $24 \mathrm{~h}$ with $20 \mathrm{ng} / \mathrm{ml} \mathrm{NGF})$. C, Correlation between [Ca $\left.{ }^{2+}\right]_{\mathrm{i}}$ elevation to high $\mathrm{K}^{+}(30 \mathrm{~mm})$ application and to a cooling pulse in individual neurons. ${ }^{*} p<0.05$.

cold sensitivity. To this end, recordings were obtained from neurons cultured for different times in the absence of NGF. As shown in Figure $2 A$, neither the time in culture nor the absence of NGF had any effect on the percentage of CS neurons, which was $>50 \%$ in all cases. The only notable difference was the smaller amplitude of cold-evoked responses at $2 \mathrm{~h}$ after dissociation compared with the rest of the observations (one-way ANOVA and post hoc Tukey test) (Fig. 2B), which may be attributable to acute effects of the enzymatic treatment on cellular excitability. In agreement with this thesis, we observed a significant reduction in the amplitude of $\left[\mathrm{Ca}^{2+}\right]_{\mathrm{i}}$ responses to high $\mathrm{KCl}(30 \mathrm{~mm})$ at $2 \mathrm{~h}$ compared with longer cultures (ANOVA, $p=0.005$ ). Furthermore, there was a significant correlation $(r=0.55 ; p<$ $0.001)$ between cold-evoked $\left[\mathrm{Ca}^{2+}\right]_{\mathrm{i}}$ responses and $\left[\mathrm{Ca}^{2+}\right]_{\mathrm{i}}$ elevations produced by a brief pulse of $30 \mathrm{~mm} \mathrm{~K}^{+}$to depolarize the cell (Fig. 2C).

Cold-evoked responses require extracellular calcium influx Removing extracellular $\mathrm{Ca}^{2+}$ had a large impact on cold-evoked responses. In 20 of $26 \mathrm{CS}$ neurons, cold-evoked $\left[\mathrm{Ca}^{2+}\right]_{\mathrm{i}}$ elevations were abolished (Fig. $3 A$ ). In the remaining six cells, coldevoked $\left[\mathrm{Ca}^{2+}\right]_{\mathrm{i}}$ elevations were substantially reduced from $157 \pm$ $60 \mathrm{~nm}$ to $40 \pm 8 \mathrm{~nm}(p<0.001)$. We also tested the potential involvement of internal stores and calcium-induced calcium release on the cold-evoked $\left[\mathrm{Ca}^{2+}\right]_{\mathrm{i}}$ elevations. To this end, neurons were incubated for $60 \mathrm{~min}$ in $1 \mu \mathrm{M}$ thapsigargin, an inhibitor of sarco/endoplasmic reticulum $\mathrm{Ca}^{2+}$ /ATPase pump that depletes calcium stores (Inesi et al., 2005). After thapsigargin treatment mean basal $\left[\mathrm{Ca}^{2+}\right]_{\mathrm{i}}$ was substantially elevated $(264 \pm 19 \mathrm{nM} \mathrm{com}-$ pared with $96 \pm 2 \mathrm{~nm}$; unpaired $t$ test, $p<0.001)$ and mean
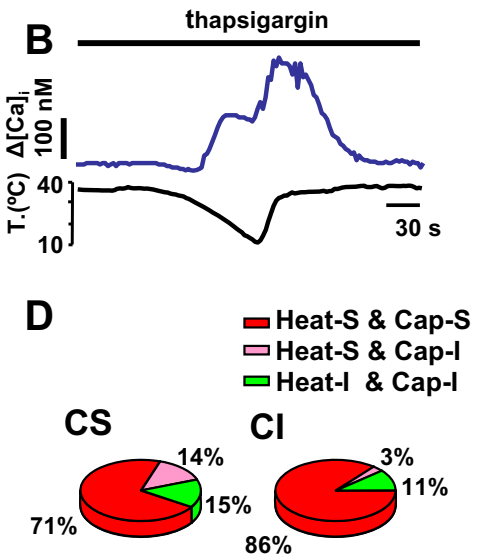

Figure 3. Pharmacological properties of cold-evoked response in the nodose ganglion. $\boldsymbol{A}$, Removal of extracellular calcium solution during the cooling ramp completely abolished the cold-evoked $\left[\mathrm{Ca}^{2+}\right]_{i}$ response. The effect of calcium removal was

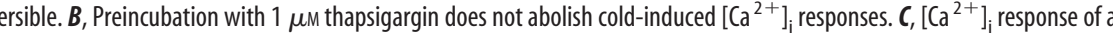
nodose neurons showing responses to cooling, heating, and $100 \mathrm{~nm}$ capsaicin (blue trace). Other CI neurons (red trace) were also sensitive to heat and capsaicin. D, Pie chart showing the distribution of heat and capsaicin sensitivity among CS and Cl neurons. The majority of neurons in both groups responded to these two stimuli. Heat-S, Heat sensitive; Heat-I, heat insensitive; Cap-S, capsaicin sensitive; Cap-I, capsaicin insensitive.

$\left[\mathrm{Ca}^{2+}\right]_{\mathrm{i}}$ elevation during cooling was $304 \pm 60 \mathrm{nM}(n=14)$, with the signal clearly outlasting the temperature drop (Fig. $3 B$ ). The thermal threshold was $27 \pm 1.2^{\circ} \mathrm{C}$. Altogether, these results indicate that in nodose neurons cold-evoked $\left[\mathrm{Ca}^{2+}\right]_{\mathrm{i}}$ signals depend on the activation of a calcium influx pathway.

\section{Nodose cold-sensitive neurons are polymodal}

We tested heat stimuli and capsaicin on 51 neurons, 14 of which were CS and $37 \mathrm{CI}$ (Fig. 3C). Twelve of the $14 \mathrm{CS}$ neurons tested also responded to heat $\left(\Delta \mathrm{Ca}^{2+}=329 \pm 70 \mathrm{~nm}\right.$; threshold, $38.5 \pm$ $0.6^{\circ} \mathrm{C}$ ). Of these 12 neurons, 10 also responded to $100 \mathrm{~nm}$ capsaicin $\left(\Delta \mathrm{Ca}^{2+}=491 \pm 101 \mathrm{nM}\right)$. Seven of $12 \mathrm{CS}$ neurons tested also responded to $100 \mu \mathrm{M}$ cinnamaldehyde $\left(\Delta \mathrm{Ca}^{2+}=402 \pm 92 \mathrm{nM}\right)$ (see below). These results indicate that the majority of nodose CS 

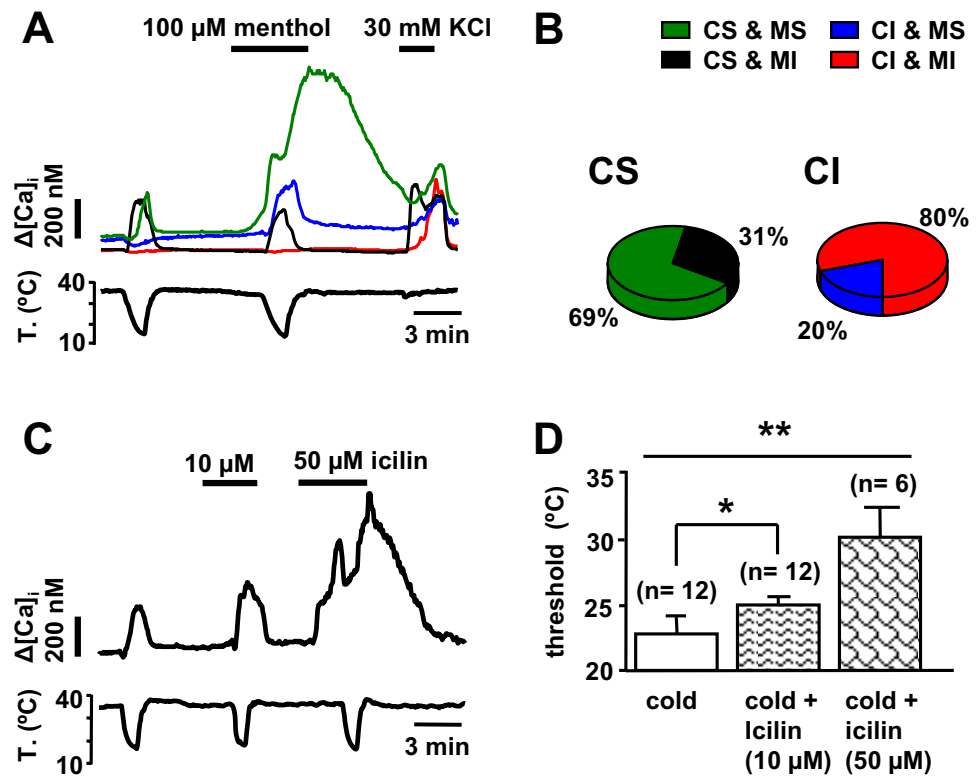

Figure 4. Response of nodose neurons to menthol and icilin. $\boldsymbol{A}$, Simultaneous recording of $\left[\mathrm{Ca}^{2+}\right]_{\mathrm{i}}$ (top trace) and bath temperature (bottom trace) in four nodose neurons showing the different responses to $100 \mu \mathrm{m}$ menthol. The majority of CS neurons were potentiated by menthol (CS-MS, green trace), the rest were insensitive or slightly inhibited by menthol (CS-MI, black trace). In contrast, the majority of CI neurons were insensitive to menthol (Cl-MI, red trace) and only a small fraction were sensitized by menthol (CI-MS, blue trace). $\boldsymbol{B}$, Distribution of responses to menthol among $\mathrm{CS}$ and $\mathrm{Cl}$ neurons. $\boldsymbol{C}$, Response of a CS nodose neuron to 10 and $50 \mu \mathrm{m}$ icilin. $\boldsymbol{D}$, Average effects of 10 and $50 \mu \mathrm{m}$ icilin on thermal threshold. ${ }^{*} p<0.05{ }^{* *} p<0.01$.

during cooling in the presence of menthol (blue trace), with a mean threshold of $27 \pm$ $0.9^{\circ} \mathrm{C}$ and mean $\left[\mathrm{Ca}^{2+}\right]_{\mathrm{i}}$ response of $157 \pm$ $16 \mathrm{nM}$. Altogether, only $20 \%$ of CI neurons were activated $(4 \%)$ or sensitized $(16 \%)$ by menthol, a lower percentage when compared with CS neurons ( $\chi^{2}$ test, $p<0.001$ ) (Fig. $4 B$ ).

Icilin is a compound that potently activates TRPM8 but has also weaker agonist effects on TRPA1 (McKemy et al., 2002; Chuang et al., 2004). Icilin (10 and $50 \mu \mathrm{M}$ ) produced a dose-dependent activation of CS neurons (Fig. 4C). Applied at $10 \mu \mathrm{M}$ icilin did not evoke a response at $35^{\circ} \mathrm{C}$ but shifted the cold activation threshold to warmer temperatures $\left(\Delta T=2.2 \pm 0.9^{\circ} \mathrm{C}\right.$; $n=12 ; p=0.03)$ and increased the mean calcium response during cooling $\left(\Delta \mathrm{Ca}^{2+}\right.$ $=133 \pm 25$ in control solution vs $216 \pm 35$ $\mathrm{nM}$ in the presence of icilin; $p=0.01$ ) (Fig. $4 C, D)$. In addition, three cells (18\%) classified as CI in control solution became CS in the presence of icilin. Application of 50 $\mu \mathrm{M}$ icilin produced qualitatively similar effects, with a stronger shift in threshold $\left(\Delta T=5.4 \pm 3.4^{\circ} \mathrm{C} ; n=6\right.$; one-way ANOVA $p=0.003$ ) (Fig. $4 D$ ). At this

also respond to heat and to pungent compounds, typical characteristics of polymodal nociceptors (Fig. 3D). Among CI neurons, the majority $(86 \%)$ also responded to heat $\left(\Delta \mathrm{Ca}^{2+}=285 \pm 33\right.$ nM; threshold, $39.6 \pm 0.3^{\circ} \mathrm{C}$ ) and nearly all (32 of 33 ) heatsensitive neurons also responded to capsaicin $\left(\Delta \mathrm{Ca}^{2+}=404 \pm\right.$ $47 \mathrm{~nm}$ ) (Fig. 3D). No heat-insensitive neurons showed a response to capsaicin.

\section{Effects of menthol and icilin on cold-evoked responses}

Menthol potently activates TRPM8 channels (McKemy et al., 2002; Peier et al., 2002), sensitizing their response to cooling stimuli (Voets et al., 2004). However, menthol has been shown to modulate activity of TRPA1 as well (Macpherson et al., 2006; Karashima et al., 2007). We investigated the action of menthol on 297 nodose neurons, comparing the action on CS $(n=132)$ and CI $(n=165)$ neurons (Fig. $4 A)$. Application of $100 \mu \mathrm{M}$ menthol at $35^{\circ} \mathrm{C}$ evoked $\left[\mathrm{Ca}^{2+}\right]_{\mathrm{i}}$ responses in $36 \%$ of CS nodose neurons (green trace) but only in $4 \%$ of CI neurons (data not shown). These percentages were significantly different $\left(\chi^{2}\right.$ test, $p<$ $0.001)$. Lowering the bath temperature in the presence of $100 \mu \mathrm{M}$ menthol sensitized the cold response in an additional 33\% of CS neurons, which shifted their threshold temperature to warmer temperatures $\left(\Delta T=7.5 \pm 0.5^{\circ} \mathrm{C}\right.$; paired $t$ test, $\left.p<0.001\right)$ and increased their calcium response $\left(\Delta \mathrm{Ca}^{2+}=98 \pm 27 \mathrm{nM}\right.$ in control solution vs $234 \pm 31 \mathrm{nM}$ in the presence of menthol; paired $t$ test, $p<0.001)$. In $14 \%$ CS cells, cold threshold did not change by more than $\pm 2{ }^{\circ} \mathrm{C}$ in the presence of menthol, neither changed the amplitude of the calcium response $\left(\Delta \mathrm{Ca}^{2+}=142 \pm 30 \mathrm{nM}\right.$ vs $150 \pm 26 \mathrm{~nm}$; paired $t$ test, $p=0.67)$. Finally, in $17 \%$ the threshold shifted to colder temperatures $\left(\Delta T=-6 \pm 0.8^{\circ} \mathrm{C}\right.$; paired $t$ test, $p<0.001)$, although their calcium response did not change significantly $\left(\Delta \mathrm{Ca}^{2+}=136 \pm 18 \mathrm{nM}\right.$ vs $122 \pm 22 \mathrm{nM}$; paired $t$ test, $p=0.42)$. Overall, the majority $(69 \%)$ of CS neurons were activated or sensitized by $100 \mu \mathrm{M}$ menthol (Fig. 4 B). Of all neurons classified as CI when cooled in control solution, $16 \%$ became CS higher concentration, three of six neurons also responded at $35^{\circ} \mathrm{C}$ (Fig. $4 C$ ) and one additional CI neuron became CS.

In conclusion, the results obtained with menthol and icilin are similar (although icilin is less potent than menthol) and indicate that $\sim 70 \%$ of all nodose CS neurons are also activated by these agonists of TRM 8 and TRPA1. To discriminate between these two targets, we took advantage of the action of more selective agonists and antagonists.

\section{Nodose CS neurons respond specifically to TRPA1 agonists}

In addition to activation by intense cold, TRPA1 channels are activated by an extensive battery of chemical compounds known to evoke pungent, painful sensations (Bandell et al., 2004; Macpherson et al., 2005; Bautista et al., 2006; García-Añoveros and Nagata, 2007). Among them, CM is considered highly specific. We tested CM $(50-100 \mu \mathrm{M})$ on 118 cells, 60 of which were $\mathrm{CS}$ and 58 of which were CI. At $35^{\circ} \mathrm{C}, \mathrm{CM}$ evoked a calcium increase in $82 \%$ of CS neurons $\left(\Delta \mathrm{Ca}^{2+}=421 \pm 42 \mathrm{nM}\right)$ and in only $15 \%$ of CI cells $\left(\Delta \mathrm{Ca}^{2+}=262 \pm 71 \mathrm{nM}\right)$ (Fig. $\left.5 A\right)$. The correlation between sensitivity to cold and to CM was highly significant ( $\chi^{2}$ test, $\left.p<0.001\right)$. We also tested the effects of menthol $(100 \mu \mathrm{M})$ on 66 neurons of the same sample (data not shown). Among the $30 \mathrm{CM}$-sensitive cells, 24 were also menthol sensitive. In contrast, from the $36 \mathrm{CM}$-insensitive cells only three were menthol sensitive. These results show that there is a high and significant correlation between the sensitivity to these two chemical compounds ( $\chi^{2}$ test, $\left.p<0.001\right)$. As shown on the Venn diagram in Figure $5 B$, there is a strong overlap between in the sensitivity to cold, menthol and CM among neurons in the nodose ganglion.

Recently, we identified the L-type calcium channel blocker nifedipine as a potent agonist of recombinant mouse TRPA1 channels (supplemental Fig. 1, available at www.jneurosci.org as supplemental material). Thus, we tested the effect of nifedipine $(10 \mu \mathrm{M})$ on nodose sensory neurons. Eight of nine CS neurons 

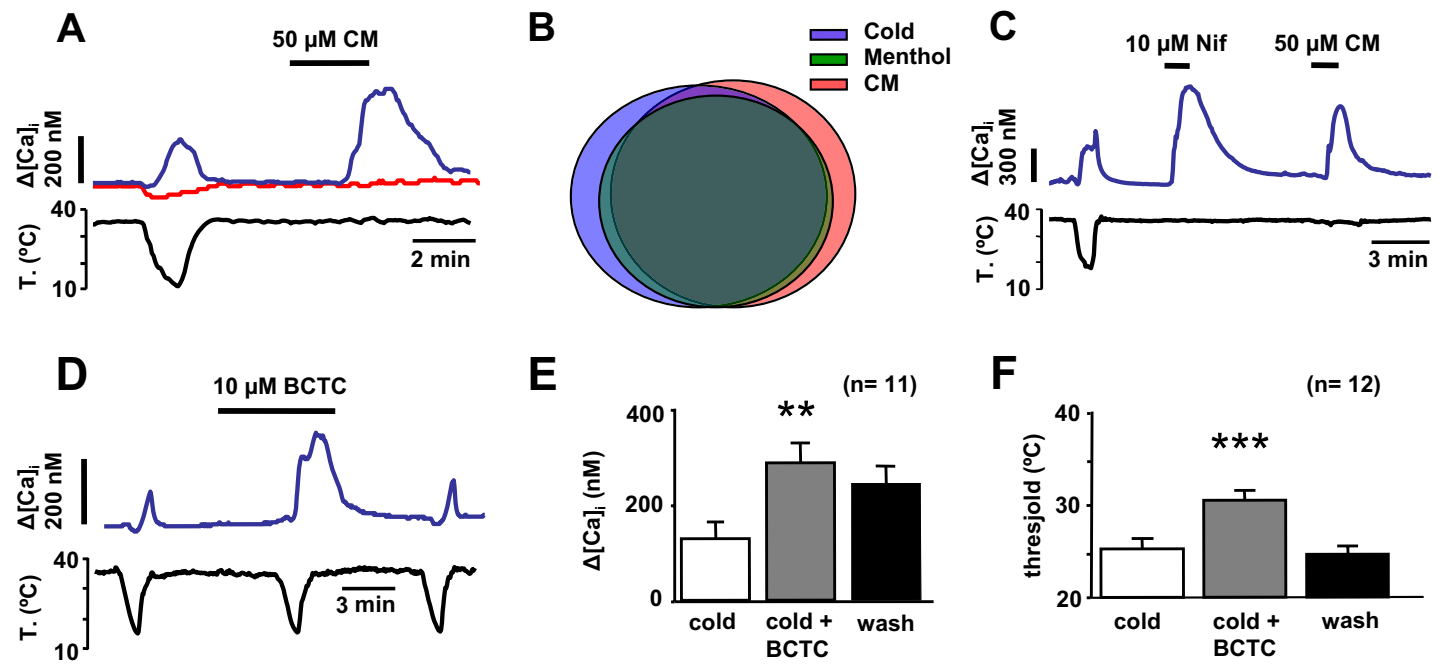

Figure 5. Response of nodose neurons to specific TRPA1 agonists. $A$, Simultaneous recording of $\left[\mathrm{Ca}^{2+}\right]_{\mathrm{i}}$ (top trace) and bath temperature (bottom trace) showing the response of a $C S$ neuron (blue trace) to $50 \mu \mathrm{M} \mathrm{CM}$. In contrast, a typical CI neuron (red trace) recorded from the same optical field lacked a response to CM. $\boldsymbol{B}$, Venn diagram showing the overlap in the sensitivity to menthol and cinnamaldehyde among $C S$ nodose neurons. Most neurons responded to these three stimuli. C, Simultaneous recording of $\left[\mathrm{Ca}^{2+}\right]_{\mathrm{i}}$ (top trace) and bath temperature (bottom trace) showing the correspondence between responses to cold, $10 \mu \mathrm{m}$ nifedipine, and $50 \mu \mathrm{M} C \mathrm{M} . \mathrm{D},\left[\mathrm{Ca}^{2+}\right]_{\mathrm{i}}$ response of a $\mathrm{CS}$ nodose neuron, showing the potentiation of the response to cooling by application of 10 $\mu м$ BCTC. $\boldsymbol{E}, \boldsymbol{F}$, Summary histogram of effects of BCTC on cold-evoked $\left[\mathrm{Ca}^{2+}\right]_{\mathrm{i}}$ responses $(\boldsymbol{E})$ and thermal threshold $(\boldsymbol{F})$. Error bars indicate $\mathrm{SEM} .{ }^{* *} p<0.01 ;{ }^{* * *} p<0.001$.

examined showed a robust $\left[\mathrm{Ca}^{2+}\right]_{\mathrm{i}}$ increase $(546 \pm 79 \mathrm{nM})$ to nifedipine at $35^{\circ} \mathrm{C}$ (Fig. $5 \mathrm{C}$ ). Nine of $18 \mathrm{CI}$ neurons also responded to nifedipine $(236 \pm 79 \mathrm{nM})$, a significantly lower percentage $\left(\chi^{2}\right.$ test $\left.=0.049\right)$. After recovery from the nifedipine pulse, we applied CM in 19 neurons: 9 of 10 cells sensitive to nifedipine were also sensitive to CM (Fig. $5 C$ ) and only 1 of 8 cells insensitive to nifedipine was sensitive to CM. There is a statistically significant relationship between the nifedipine and CM sensitivity, consistent with the agonist action of nifedipine on TRPA1.

BCTC is an interesting compound that modulates various thermoTRP channels: it blocks TRPV1 (Valenzano et al., 2003; Behrendt et al., 2004) and cold- and menthol-evoked responses mediated by TRPM8 in native and expressed channels (Behrendt et al., 2004; Madrid et al., 2006). In contrast, it activates recombinant TRPA1 channels (Madrid et al., 2006). We tested $10 \mu \mathrm{M}$ BCTC on 20 nodose neurons, 13 of which were CS, and 7 CI. BCTC did not evoke a $\left[\mathrm{Ca}^{2+}\right]_{\mathrm{i}}$ rise at $35^{\circ} \mathrm{C}$; however, it potentiated the amplitude of cold-evoked responses in the majority (11 of 13) of CS neurons (Fig. 5D). The potentiation averaged $120 \pm$ $32 \%$ (Student's paired $t$ test, $p<0.01$ ) (Fig. $5 E$ ). Furthermore, on most CS neurons (12 of 13), BCTC shifted reversibly the threshold temperature to warmer values $\left(\Delta T=6 \pm 1^{\circ} \mathrm{C}\right.$; paired $t$ test, $p<0.001$ ) (Fig. 5F). We also tested menthol $(100 \mu \mathrm{M})$ and $\mathrm{CM}$ $(50 \mu \mathrm{M})$ on these $13 \mathrm{CS}$ neurons. The $12 \mathrm{CS}$ neurons sensitive to BCTC were also sensitized by menthol, and nine of them also showed a $\left[\mathrm{Ca}^{2+}\right]_{\mathrm{i}}$ increase with $\mathrm{CM}$. One CS neuron was insensitive to the three TRPAl agonists (CM, BCTC and menthol). In marked contrast, BCTC had no effect on the seven CI neurons tested.

In summary, these results indicate that cold-evoked responses in CS nodose neurons were generally potentiated by application of TRPA1-activating compounds, strongly suggesting their expression and their role in mediating cold-evoked responses in these neurons. In a small fraction of neurons $(<10 \%)$ sensitivity to cold is independent of TRPA1 expression and is probably mediated by a different molecular cold sensor.

\section{Cold-evoked responses in nodose neurons are blocked by TRPA1 antagonists}

To further test the role of TRPA1 in visceral cold sensing, we explored the effects of TRPA1 antagonists on cold-evoked responses in nodose sensory neurons. Ruthenium red blocks TRPA1-mediated cold-evoked responses (Story et al., 2003) while lacking effects on TRPM8 (Peier et al., 2002; Behrendt et al., 2004). We tested 50-20 $\mu \mathrm{M}$ RR on 106 nodose neurons, 17 of which were CS (Fig. 6A). In 13 CS neurons RR attenuated the cold-evoked response by $84 \pm 7 \%$ (Student's paired $t$ test, $p=$ 0.003 ) (Fig. 6B). In the remaining four CS neurons, RR did not affect the cold-evoked response ( $37 \pm 4 \mathrm{~nm}$ vs $204 \pm 152 \mathrm{~nm} ; p=$ $0.35)$.

The efficacy of more specific blockers of TRPA1 was verified by testing first their effects on cold-evoked whole-cell currents in a cell line expressing TRPA1 (see Materials and Methods). As shown in supplemental Figure 2, $A$ and $B$ (available at www. jneurosci.org as supplemental material), $2 \mathrm{~mm}$ camphor, an effective blocker of chemical responses in TRPA1 channels (Xu et al., 2005), produced a clear inhibition $(80 \pm 6 \% ; n=4$; $p=$ 0.022 ) of TRPA 1 currents activated by cooling pulses. In contrast, camphor had no effect on cold-evoked responses mediated by TRPM8 (mean activation, $20 \pm 13 \% ; n=5 ; p=0.71$ ), which were readily blocked by BCTC (mean inhibition, $69 \pm 12 \%$; $n=$ $4 ; p=0.027$ ) (supplemental Fig. $2 C, D$, available at www. jneurosci.org as supplemental material). In addition to blocking effects on TRPA1, high concentrations of camphor can also activate TRPV3 and TRPV1 channels (Moqrich et al., 2005; Xu et al., 2005). At $2 \mathrm{~mm}$ camphor had a dual effect on $\left[\mathrm{Ca}^{2+}\right]_{\mathrm{i}}$ levels in nodose neurons: it produced a $\left[\mathrm{Ca}^{2+}\right]_{\mathrm{i}}$ elevation in some neurons at $35^{\circ} \mathrm{C}$ (gray trace) and a full suppression of cold-evoked responses (black trace) (Fig. 6C), strongly suggesting effects on more than one native channel. We tested camphor on 26 nodose neurons (14 CS and $12 \mathrm{CI}$ ). At $35^{\circ} \mathrm{C}$ it produced an average $\left[\mathrm{Ca}^{2+}\right]_{\mathrm{i}}$ increment of $130 \pm 38 \mathrm{~nm}$ on 19 neurons (10 CS and 9 CI). There was no statistically significant relationship between this effect of camphor and cold sensitivity $\left(\chi^{2}\right.$ test, $\left.p=0.8\right)$ 
A
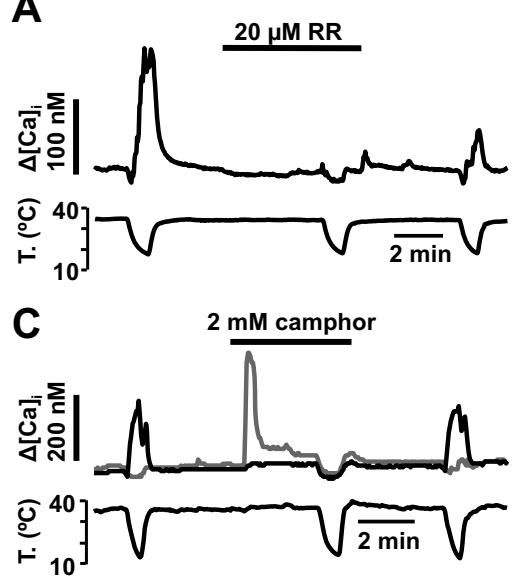

E

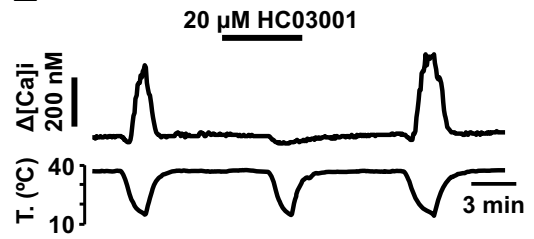

B



D

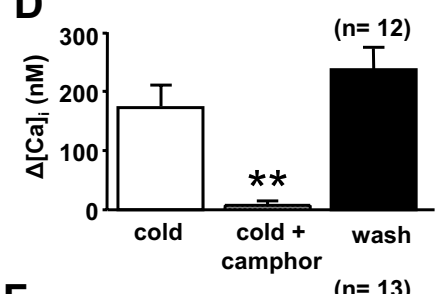

F

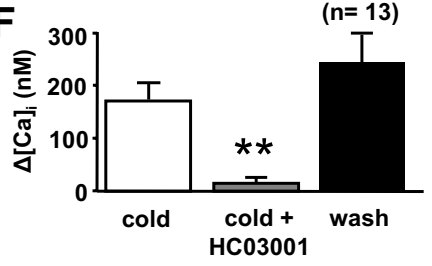

Figure 6. Nodose cold-evoked responses are blocked by TRPA1 antagonists. $\boldsymbol{A},\left[\mathrm{Ca}^{2+}\right]_{\mathrm{i}}$ response of a $\mathrm{CS}$ neuron to cooling and cooling in the presence of $20 \mu \mathrm{m}$ ruthenium red. The inhibition was only partially reversible. $\boldsymbol{B}$, Mean effect of $20-50 \mu \mathrm{m}$ ruthenium red on cold-evoked responses. Data include 13 neurons inhibited by ruthenium red and excludes four neurons that were unaffected. $\boldsymbol{C},\left[\mathrm{Ca}^{2+}\right]_{\mathrm{i}}$ response of a $\mathrm{CS}$ neuron (black) and a $\mathrm{Cl}$ neuron (gray) to cooling and cooling in the presence of $2 \mathrm{~mm}$ camphor. The cold-evoked response was abolished by camphor. In contrast, note the response to camphor in the $\mathrm{CI}$ neuron at $35^{\circ} \mathrm{C}$. D, Mean effect of 2 mm camphor on cold-evoked responses. Data include 12 neurons inhibited by camphor and excludes two neurons that were potentiated. $\boldsymbol{E}$, Full blockade of the cold-evoked $\left[\mathrm{Ca}^{2+}\right]_{\mathrm{i}}$ response in a nodose neuron by $20 \mu \mathrm{M} \mathrm{HC03001.} \boldsymbol{F}$, Mean effect of $20 \mu \mathrm{m} \mathrm{HCO3001}$ on cold-evoked responses in nodose neurons. Data include 13 neurons inhibited by HC03001 and exclude one neuron that was unaffected. ${ }^{* *} p<0.01$.

suggesting the absence of a common causal relationship between both responses. In contrast, cold-evoked responses were fully blocked by camphor on 11 of 14 CS neurons and this effect was reversible after washing out the drug (Fig. $6 C, D$ ). In one of the remaining three CS neurons, the cold response was partially inhibited, and in the other two it was sensitized. In these three cells the effects were also reversible by washing. We also tested the effect of CM $(25 \mu \mathrm{M})$ on 17 cells, 7 CS and 10 CI. At this concentration, $\mathrm{CM}$ produced a $\left[\mathrm{Ca}^{2+}\right]_{\mathrm{i}}$ increment of $345 \pm 95 \mathrm{nM}$ on eight cells, seven of which were CS (data not shown).

HC03001 is a specific antagonist of chemical responses in TRPA1 channels (McNamara et al., 2007). In CHO cells expressing mTRPA1, we found that $20 \mu \mathrm{M}$ HC03001 abolished coldevoked responses in a reversible manner (supplemental Fig. $2 E, F$, available at www.jneurosci.org as supplemental material). Similarly, in 11 of 14 CS neurons, $20 \mu \mathrm{M}$ HC03001 abrogated cold-evoked responses fully and reversibly (Fig. $6 E$ ). In two other CS cells, the response was inhibited by 25 and $20 \%$, respectively. Finally, in the remaining CS cell, the cold-evoked response was unchanged. A summary of these findings is presented in Figure 6 F. Application of HC03001 had no effect on 30 CI neurons (data not shown). Altogether, these results strongly suggest that TRPA1 channels are the principal influx pathway for cold-evoked $\left[\mathrm{Ca}^{2+}\right]_{\mathrm{i}}$ elevations in rat nodose sensory neurons.

Cold-evoked responses are reduced in TRPA1 knock-out mice To verify the involvement TRPA1 channels in visceral cold sensing, we compared cold-evoked $\left[\mathrm{Ca}^{2+}\right]_{i}$ responses between nodose ganglion neurons of wild-type and TRPA1 $(-/-)$ mice. Of a total of 110 neurons derived from wildtype animals, 19 (17\%) were CS, a lower fraction than in rats $\left(\chi^{2}\right.$ test, $\left.p<0.001\right)$. Cold threshold temperature varied widely in individual cells (range, $32-13^{\circ} \mathrm{C}$ ) with a mean of $21.4 \pm 1.0^{\circ} \mathrm{C}$. We also tested sensitivity to $\mathrm{CM}$ on these 110 neurons. Among the fraction of CS neurons, 15 $(79 \%)$ showed a $\left[\mathrm{Ca}^{2+}\right]_{\mathrm{i}}$ response to $\mathrm{CM}$ (422 $\pm 80 \mathrm{~nm})$. In contrast, not a single cell was activated by $\mathrm{CM}$ in the population of cold-insensitive neurons. Thus, similar to our finding in rats, there was a strong correlation between sensitivity to $\mathrm{CM}$ and responsiveness to cold ( $\chi^{2}$ test, $p<0.001$ ).

Next, we tested the effect of the specific TRPA1 blocker HC03001 (20 $\mu \mathrm{M})$ on cold-evoked responses. In 14 of 19 cells (74\%), HC03001 inhibited the $\left[\mathrm{Ca}^{2+}\right]_{\mathrm{i}}$ response to cold temperature by $98 \pm 2 \%$ ( $227 \pm 45 \mathrm{~nm}$ vs $3 \pm 3 \mathrm{~nm}$; Student's paired $t$ test, $p<0.001$ ) (Fig. 7A). Furthermore, all neurons inhibited by HC03001 showed a strong $\left[\mathrm{Ca}^{2+}\right]_{\mathrm{i}}$ response when probed with $50 \mu \mathrm{M} \mathrm{CM}(430 \pm 86 \mathrm{~nm})$ (Fig. $7 A)$. In contrast, of the five neurons unaffected by HC03001 (71 $\pm 17 \mathrm{nM}$ in control solution vs $90 \pm 27 \mathrm{~nm}$ in HC03001; $p=0.22$ ) only one was activated by CM.

These results show that, as in rats, two populations of CS nodose neurons are also present in mice: a larger subpopulation whose response to cold was inhibited by HC03001 and excited by CM (TRPA1 dependent) and a smaller subpopulation $(\sim 30 \%)$ of CS neurons insensitive to $\mathrm{CM}$ and with responses to cold that were not inhibited by HC03001 (TRPA1 independent) (Fig. 7B). The amplitude of cold-evoked $\left[\mathrm{Ca}^{2+}\right]_{\mathrm{i}}$ responses was significantly larger in the TRPA1-dependent population $(227 \pm 39 \mathrm{~nm}$ vs $71 \pm 17 \mathrm{nM} ; p=$ 0.002 ) (Fig. $7 C$ ). In contrast, thermal threshold $\left(21.9 \pm 1.2^{\circ} \mathrm{C}\right.$ vs $\left.20.0 \pm 2.4^{\circ} \mathrm{C} ; p=0.42\right)$ and cell diameter $(24.0 \pm 1.5 \mu \mathrm{m}$ vs $23.1 \pm 1.7 \mu \mathrm{m} ; p=0.75)$ were similar.

Next, we assessed the cold sensitivity of cultured nodose neurons from TRPA1(-/-) mice (Kwan et al., 2006). We recorded from a total of 179 neurons, only 10 of which (6\%) were CS (Figure $7 D)$. This proportion was significantly smaller compared with the one observed in TRPA1 $(+/+)$ mice $\left(\chi^{2}\right.$ test, $\left.p<0.001\right)$. As expected, none of the 179 neurons responded to application of CM. We also tested HC03001 $(20 \mu \mathrm{M})$ on these neurons. As shown in Figure $7 C$, the drug did not affect $\left[\mathrm{Ca}^{2+}\right]_{\mathrm{i}}$ levels in CI neurons, neither did it block cold-evoked responses in CS neurons $(69 \pm 12 \mathrm{nM}$ in control solution vs $116 \pm 39 \mathrm{nM}$ in the presence of $\mathrm{HC} 03001 ; p=0.23$ ), indicating a good specificity of the compound against TRPA1. Furthermore, cold-evoked $\left[\mathrm{Ca}^{2+}\right]_{\mathrm{i}}$ responses in TRPA1(-/-) mice were small in amplitude (Fig. $7 F$ ), similar to responses in the TRPA1-independent population of wild-type mice ( $p=0.92$ ), but significantly smaller than responses in the TRPA1-dependent population of these same mice. In contrast, no difference was observed in thermal threshold or cell diameter between the different subgroups (data not shown).

Altogether, these results indicate that TRPA1 is the principal mediator of cold-evoked responses in mice nodose neurons. 
They also show that, as was the case in the rat, a smaller subpopulation of neurons is activated by cold through a TRPA1independent mechanism.

\section{Electrophysiology of cold-evoked responses in nodose neurons}

We used perforated-patch current-clamp recordings, combined with simultaneous $\left[\mathrm{Ca}^{2+}\right]_{\mathrm{i}}$ imaging, to further characterize the ionic mechanisms underlying coldevoked responses in rat nodose neurons. In seven CS neurons, the mean depolarization during a cooling ramp to $\sim 15^{\circ} \mathrm{C}$ was $21 \pm 4 \mathrm{mV}$ and all neurons reached the firing threshold for action potentials (Fig. $8 A$ ). The mean temperature threshold for firing was $25.6 \pm 1.8^{\circ} \mathrm{C}$. The depolarization was accompanied by an elevation in the $\left[\mathrm{Ca}^{2+}\right]_{\mathrm{i}}$ level that averaged $331 \pm 86$ nм (Fig. 8A) In contrast, CI neurons had minimal responses to cooling ramps: on average, they hyperpolarized by $1.0 \pm$ $2.8 \mathrm{mV}$, none reached firing threshold, and the $\left[\mathrm{Ca}^{2+}\right]_{\mathrm{i}}$ elevation to cooling averaged only $9 \pm 2 \mathrm{~nm}(n=8)$ (Fig. $8 B$ ). Basic electrophysiological properties of CS and CI neurons were undistinguishable (Table 1).

Application of $2 \mathrm{~mm}$ camphor strongly reduced cold-evoked depolarizations in nodose neurons (Fig. 8C). The mean depolarization in camphor was reduced from $24 \pm 6 \mathrm{mV}$ to $7 \pm 6 \mathrm{mV}$ $(p<0.001 ; n=4)$ (Fig. 8D). In all cases, the residual depolarization in camphor was subthreshold for action potential firing. The $\left[\mathrm{Ca}^{2+}\right]_{\mathrm{i}}$ elevation that accompanies the cold-induced depolarization was fully blocked by camphor in two of four neurons and in the other two it was reduced by 71 and $18 \%$, respectively (Fig. 8D).

Next, we assessed the effects of cooling ramps on ionic conductances and $\left[\mathrm{Ca}^{2+}\right]_{\mathrm{i}}$ in CS and CI neurons under voltageclamp conditions. Cells were held at $-60 \mathrm{mV}$. As shown in Figure $8 E$, in CS neurons, identified previously by calcium imaging, cooling was accompanied by the development of a small inward current that recovered with rewarming. The cold-induced current averaged $-0.59 \pm 0.14 \mathrm{pA} / \mathrm{pF}(n=6)$. In all six neurons, a slowly developing $\left[\mathrm{Ca}^{2+}\right]_{\mathrm{i}}$ increase of $273 \pm 83 \mathrm{nM}$ was observed during cooling (Fig. $8 E$ ), similar to the elevation during current clamp ( $t$ test, $p=0.64$ ). We also recorded from four CI neurons under the same conditions and did not observe any inward current or $\left[\mathrm{Ca}^{2+}\right]_{\mathrm{i}}$ increase during cooling (Fig. $8 F$ ). The application of $2 \mathrm{~mm}$ camphor abolished the $\left[\mathrm{Ca}^{2+}\right]_{\mathrm{i}}$ response in five of the six CS neurons (Fig. 8G). In three of those five inhibited by camphor, the inward current was also fully suppressed, and in the other two was diminished by 40 and $20 \%$, respectively. In the only neuron that had a calcium increase in the presence of camphor, the inward current diminished by just $12 \%$ (data not shown). These results are summarized in Figure $8 \mathrm{H}$. They suggest that low temperature leads to the opening of a $\mathrm{Ca}^{2+}$-permeable conductance at $-60 \mathrm{mV}$ in nodose neurons. However, these calciumpermeable channels are not the solely conductance altered by cooling, as implied by the fact that camphor abolished the calcium response in two cells but not the inward current.
B

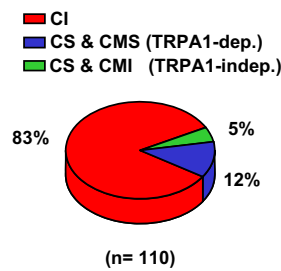

E

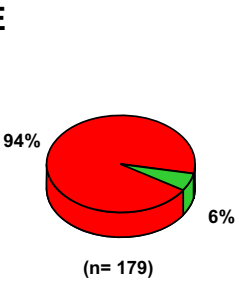

C



$\mathbf{F}$

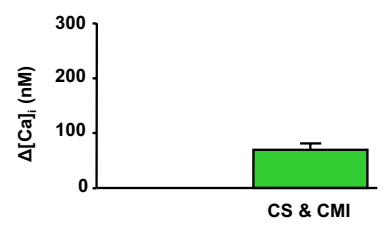

Figure 7. Cold-evoked responses are reduced in TRPA1 knock-out mice. $A$, Simultaneous recording of $\left[\mathrm{Ca}^{2+}\right]_{\mathrm{i}}$ (top trace) and ef neurons in TRPA1(-/-) mice. $F$, Mean amplitude of cold-evoked $\left[\mathrm{Ca}^{2+}\right]_{\mathrm{i}}$ responses in $C S$ neurons in TRPA1(-/-) mice. ${ }^{* *} p<$

Cold-evoked responses in vagal neurons innervating the upper airway

The vagus nerve innervates a variety of visceral targets in the thorax and abdomen. To investigate the effects of cold temperature on a subpopulation of nodose sensory neurons innervating a specific peripheral territory, we applied the retrograde fluorescence tracer DiI to the larynx of six rats (see Material and Methods). After 9-12 d, isolated cultured nodose neurons were loaded with the calcium indicator fura-2. From these ganglia, we recorded a total of 219 neurons that had similar characteristics as those obtained from uninjected animals. The proportion of CS (43\%) was nearly identical to those obtained in control animals (49\%) ( $\chi^{2}$ test, $\left.p=0.14\right)$. Their mean temperature threshold was also very similar $\left(24.0 \pm 0.2^{\circ} \mathrm{C}\right.$ vs $\left.23.2 \pm 0.5^{\circ} \mathrm{C} ; p=0.085\right)$, as well as their mean $\left[\mathrm{Ca}^{2+}\right]_{\mathrm{i}}$ response to cooling $(165 \pm 7 \mathrm{nM}$ vs $161 \pm$ $20 \mathrm{nM} ; p=0.85)$.

Of the 219 neurons studied, 51 were marked with DiI (Fig. 9A) and $18(35 \%)$ of them were CS $\left(\left[\mathrm{Ca}^{2+}\right]_{\mathrm{i}}\right.$ increase, $181 \pm 61 \mathrm{nM}$; threshold, $\left.20.8 \pm 1.0^{\circ} \mathrm{C}\right)$. We tested $50 \mu \mathrm{M}$ CM on 19 DiI-labeled neurons, 10 of which were CS and 9 of which were CI. Eight $(80 \%)$ CS neurons responded to CM (mean $\left[\mathrm{Ca}^{2+}\right]_{\mathrm{i}}$ increase, $615 \pm 175 \mathrm{nM})$, whereas only one CI $(11 \%)$ neuron responded. These proportions were significantly different $\left(\chi^{2}\right.$ test, $p<$ $0.005)$. We also tested $100 \mu \mathrm{M}$ menthol in 17 DiI-labeled neurons, 8 of which were CS. At $35^{\circ} \mathrm{C}$, four $(17 \%$ of total) cells responded with a calcium increase $(167 \pm 53 \mathrm{nM})$, three of which were CS. When lowering the temperature in the presence of menthol, two CS cells shifted their threshold to higher temperatures $(\Delta T=$ $\left.4.1 \pm 1.4^{\circ} \mathrm{C}\right)$, two CS cells did not change threshold $(\Delta T=0.5 \pm$ $\left.0.5^{\circ} \mathrm{C}\right)$, and one changed its threshold to lower temperatures $\left(\Delta T=2.3^{\circ} \mathrm{C}\right)$. However, five CI neurons (56\% of CI neurons) also responded to cooling in the presence of menthol (calcium increase, $122 \pm 39 \mathrm{nM}$; threshold, $28.4 \pm 2.4^{\circ} \mathrm{C}$ ).

In three CS neurons labeled with DiI, we tested the effect of 2 
A



C

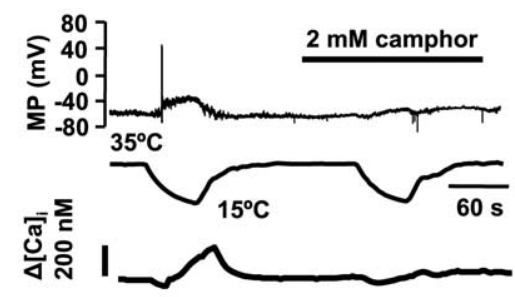

E
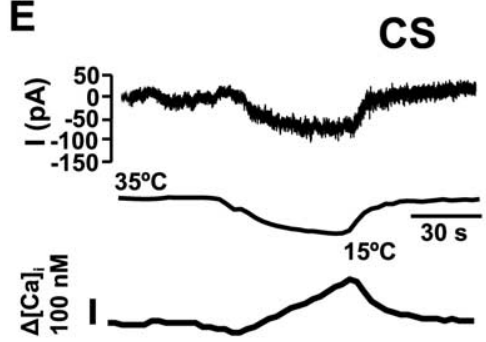

G

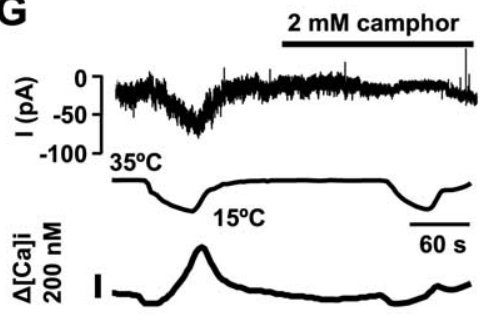

B

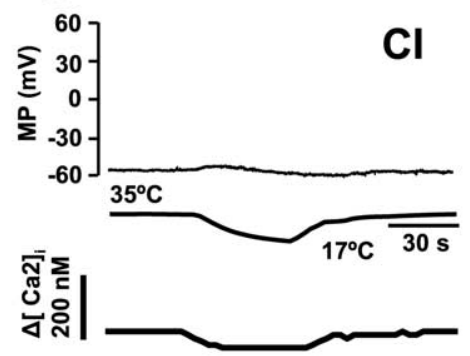

D

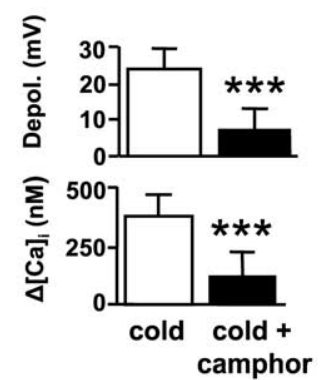

$F$

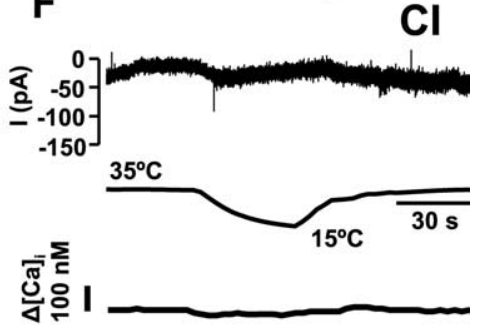

$\mathrm{H}$



Figure 8. Electrophysiology of cold-evoked responses in nodose neurons. $\boldsymbol{A}$, Simultaneous recording of membrane potential (top trace), bath temperature (middle trace) and $\left[\mathrm{Ca}^{2+}\right]_{\mathrm{i}}$ (bottom trace) in a $\mathrm{CS}$ neuron during a cooling ramp. Note the firing of action potentials and the slowly developing $\left[\mathrm{Ca}^{2+}\right]_{\mathrm{i}}$ response. $\boldsymbol{B}$, Same recording configuration from a $\mathrm{Cl}$ neuron. $\boldsymbol{C}$, Perforatedpatch current-clamp recording of a $\mathrm{CS}$ neuron showing the effect of $2 \mathrm{~mm}$ camphor on membrane potential and $\left[\mathrm{Ca}^{2+}\right]_{\mathrm{i}} . \mathbf{D}$, Summary of effects of $2 \mathrm{~mm}$ camphor on cold-evoked depolarization (top) and cold-evoked $\left[\mathrm{Ca}^{2+}\right]_{\mathrm{i}}$, elevation (bottom). $\boldsymbol{E}$, Simultaneous recording of whole-cell current at $-60 \mathrm{mV}$ (top trace), bath temperature (middle trace), and $\left[\mathrm{Ca}^{2+}\right]_{\mathrm{i}}$ (bottom trace) during a cooling ramp in a $\mathrm{CS}$ neuron identified previously by calcium imaging. $\boldsymbol{F}$, Same recording configuration from a $\mathrm{Cl}$ neuron. G, Perforated-patch voltage-clamp recording $(-60 \mathrm{mV})$ of a $\mathrm{CS}$ neuron, showing the effect of $2 \mathrm{~mm}$ camphor on membrane current and $\left[\mathrm{Ca}^{2+}\right]_{\mathrm{i}} \cdot \boldsymbol{H}$, Summary of effects of $2 \mathrm{~mm}$ camphor on cold-evoked inward current and (top) and $\left[\mathrm{Ca}^{2+}\right]_{\mathrm{i}}$, elevation (bottom) in CS neurons. Error bars indicate SEM. ${ }^{*} p<0.05$; ${ }^{* * *} p<0.001$.

Table 1. Electrophysiological properties of cold-sensitive and cold-insensitive adult rat cultured nodose neurons

\begin{tabular}{lccc}
\hline & Cold sensitive $(n=7)$ & Cold insensitive $(n=8)$ & $p$ value \\
\hline Input resistance & $340 \pm 121 \mathrm{M} \Omega$ & $317 \pm 79 \mathrm{M}$ & NS \\
Resting membrane potential & $-56 \pm 3 \mathrm{mV}$ & $-56 \pm 3 \mathrm{mV}$ & $\mathrm{NS}$ \\
Firing threshold & $-42 \pm 1 \mathrm{mV}$ & $-43 \pm 1 \mathrm{mV}$ & $\mathrm{NS}$ \\
Rheobase & $52 \pm 14 \mathrm{pA}$ & $58 \pm 13 \mathrm{pA}$ & $\mathrm{NS}$ \\
Action potential amplitude & $98 \pm 5 \mathrm{mV}$ & $101 \pm 4 \mathrm{mV}$ & NS \\
Action potential duration & $1.00 \pm 0.09 \mathrm{~ms}$ & $1.19 \pm 0.04 \mathrm{~ms}$ & NS \\
\hline
\end{tabular}

Neurons were recorded in the perforated-patch current-clamp configuration. Input resistance was measured from the slope of peak voltage response to series of negative current steps. Spike duration was measured at half amplitude.

mM camphor on the cold-evoked $\left[\mathrm{Ca}^{2+}\right]_{\mathrm{i}}$ response. In all three, the cold-evoked $\left[\mathrm{Ca}^{2+}\right]_{\mathrm{i}}$ response was strongly reduced in a reversible manner (mean inhibition, $86 \pm$ $10 \%$ ) (data not shown). In nine additional CS neurons, we tested the effect of $20 \mu \mathrm{M}$ HC03001: in seven neurons the coldevoked $\left[\mathrm{Ca}^{2+}\right]_{\mathrm{i}}$ response was completely abolished, in another neuron the response was diminished by $96 \%$, and in the remaining neuron the magnitude of the response was unaffected (Fig. $9 A, B$ ). In four DiI-labeled CS neurons, we also applied $100 \mathrm{~nm}$ capsaicin, in all of them capsaicin evoked a response (data not shown). Thus, the pharmacological phenotype of CS laryngeal neurons is very similar to the one observed in the overall population of CS nodose neurons.

The anatomical, pharmacological and functional properties of cold-evoked responses in dorsal root ganglion neurons are different from the nodose ganglion

Our results in the nodose ganglion differ substantially to previous observations from several laboratories, including our own, on the pharmacological and functional properties of cold-sensitive neurons in somatic sensory neurons of the trigeminal ganglion and DRG (McKemy et al., 2002; Reid et al., 2002; Thut et al., 2003; Madrid et al., 2006). Thus, we decided to make a direct comparison in the cold sensitivity of cultured nodose and DRG neurons, obtained from adult rats under identical experimental conditions.

In agreement with previous reports, CS neurons in DRG cultures were much less frequent than in the nodose ganglion, and were confined to a subpopulation of smalldiameter neurons. In our sample of 50 neurons, only $7(14 \%)$ responded to the cold stimulus (Fig. 10A). Furthermore, CS neurons were smaller in diameter than the CI neurons $(20 \pm 0.5 \mu \mathrm{m}$ vs $27.6 \pm 0.6$ $\mu \mathrm{m} ; p<0.001)$. In addition, $\left[\mathrm{Ca}^{2+}\right]_{\mathrm{i}}$ elevations had a significantly larger amplitude $\left(\Delta \mathrm{Ca}^{2+}=1018 \pm 206 \mathrm{nM}\right)$ and a faster time to peak compared with the nodose $(p<0.006)$. Finally, the pharmacological properties of cold-evoked responses in the DRG were strikingly different compared with the nodose. As shown in Figure $10 B$, cold-evoked responses were completely insensitive to 2 mM camphor, but were strongly inhibited by $10 \mu \mathrm{M}$ BCTC, a blocker of recombinant and native TRPM8 channels (Behrendt et al., 2004; Madrid et al., 2006; Malkia et al., 2007). A summary of these findings is shown in Figure 10C. Interestingly, 25\% of 
CI neurons in the DRG responded to 10 $\mu \mathrm{M}$ BCTC at $35^{\circ} \mathrm{C}$ or during cooling ramps, suggesting the presence of TRPA1 in these CI-insensitive cells (data not shown). We did not observe these responses in a previous study in the trigeminal ganglion (Madrid et al., 2006), probably because that study was performed in neonatal animals and TRPA 1 shows a delayed expression profile during development (Hjerling-Leffler et al., 2007).

\section{Discussion}

The mechanisms for stimulus transduction at visceral sensory endings are less well understood than those at sensory fibers innervating the skin and other somatic tissues. Our key finding is that cold sensitivity is present in a large proportion of vagal visceral sensory neurons and that TRPA1 channels appear to be the principal receptor molecule for cold thermal transduction in these neurons, in striking contrast with somatic ganglion neurons, in which TRPM8 acts as the main cold sensor. In addition, the functional and chemical phenotype of vagal coldsensitive neurons suggests that the majority of visceral neurons displaying cold sensitivity have a nociceptive function.

\section{Cold sensitivity in visceral versus somatic neurons}

There is only one previous study exploring the sensitivity to cooling of nodose ganglion neurons (Zhang et al., 2004). In that work, performed in mice, the percentage of CS neurons was $11 \pm 4 \%$, similar to our own findings in mice (18\%) and clearly lower than our observations in the rat. Thus, despite methodological differences between both studies [e.g., in the study by Zhang et al. (2004), cooling stimuli were applied from a baseline temperature of $28^{\circ} \mathrm{C}$, compared with $34-35^{\circ} \mathrm{C}$ used in the present study], a species difference appears as the main contributing factor. Furthermore, the pharmacological and genetic evidence we obtained shows that the higher percentage of CS in rats is based on expansion of a TRPA1-dependent mechanism, whereas the TRPA1independent mechanism contributes similarly to cold sensitivity in both species. The molecular mechanism behind TRPA1independent cold sensing in the nodose requires additional study.

Most CS neurons in the nodose were activated by TRPA1 agonists and also by heat and capsaicin, two well-characterized TRPV1 agonists (Caterina et al., 1997). This evidences that nodose thermosensitive ganglion neurons are polymodal and nociceptor-like, an interpretation that fits with the polymodal character of vagal afferents reported in numerous studies (Kang et al., 2004; Yu et al., 2005; Lennerz et al., 2007).

Our observations revealed important differences in coldtransduction mechanisms between peripheral sensory neurons of the somatic and the visceral system. Cold-sensitive neurons were more abundant in the rat nodose ganglion, and their mean diameter was larger. Also, In contrast with trigeminal and DRG ganglion neurons (Reid et al., 2002; Viana et al., 2002; Thut et al., 2003) the amplitude of the $\left[\mathrm{Ca}^{2+}\right]_{\mathrm{i}}$ responses to cold in nodose neurons was smaller and the mean threshold temperature lower, overlapping with the least-sensitive population of cold somatosensory neurons (Viana et al. 2002). Finally, the pharmacological profiles of somatic and visceral CS neurons were strikingly different. This was most obvious when testing selective antagonists of
B

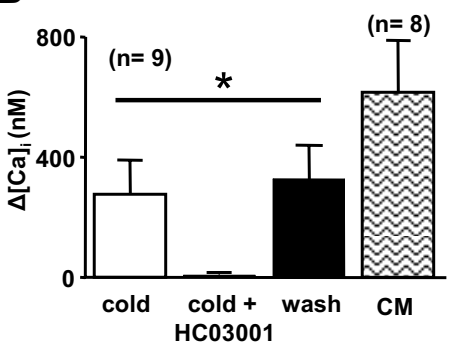



B
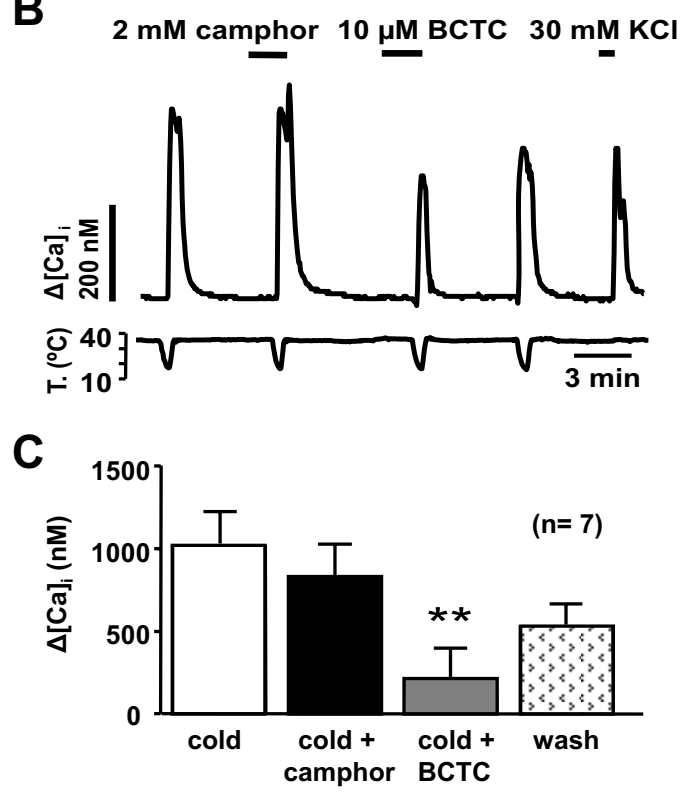

Figure 10. Properties of cold-evoked responses in dorsal root ganglion neurons. $A$, Distribution of $C S$ and $C l$ neurons in adult rat DRG cultures. $B,\left[\mathrm{Ca}^{2+}\right]_{i}$ response in a CS DRG neuron during four consecutive cooling pulses. Note the lack of effect of $2 \mathrm{~mm}$ camphor on the coldevoked response and the strong, reversible inhibition produced by $10 \mu \mathrm{M} \mathrm{BCTC}$. C, Mean $\left[\mathrm{Ca}^{2+}\right]_{\mathrm{i}}$ increase to cooling, cooling plus $2 \mathrm{~mm}$ camphor, cooling plus $10 \mu \mathrm{M} \mathrm{BCTC}$, and cooling after washout of drugs in CS DRG neurons. ${ }^{* *} p<0.01$.

TRPM8 and TRPA1, and suggests that cold sensing is mediated primarily by TRPM8 in somatic endings and by TRPA1 in vagal visceral endings. In this regard, the strong correlation between cold, menthol, and cinnamaldehyde sensitivity in nodose neurons was initially surprising and suggested a strong overlap between TRPM8 and TRPA1 expression in the nodose ganglion, unlike in DRG (Story et al., 2003). However, the recent observa- 
tion that menthol potently activates TRPA1 channels (Karashima et al., 2007) leads to the simpler explanation that menthol activates somatic and visceral CS neurons by acting on different TRP channels: TRPM8 in somatic afferents and TRPA1 in visceral endings.

To our knowledge, no previous studies investigated coldevoked electrophysiological responses in nodose neurons. Impulse firing and intracellular calcium rises in response to cold had a slow time course and a relatively high cold threshold. Basic electrophysiological properties of CS and CI vagal neurons were similar, suggesting that transducing capacities in this class of neurons do not correlate closely with their intrinsic membrane properties, contrarily to somatic neurons. This observation is in agreement with the study of (Bielefeldt et al., 2006), in which no differences in membrane properties were noticed between mechanosensitive and mechanoinsensitive gastric vagal neurons of the rat.

\section{Contribution of TRPA1 to cold sensing at visceral neurons}

Our results strongly suggest that TRPA1 channels are the principal mediators of excitation and cold-evoked $\left[\mathrm{Ca}^{2+}\right]_{\mathrm{i}}$ elevations during cooling in a large majority of nodose neurons. Cold sensitivity was closely correlated with responses to all TRPA1 agonists tested (cinnamaldehyde, menthol, nifedipine, icilin, and BCTC). Furthermore, ruthenium red, camphor, and HC03001, antagonists of TRPA1, abrogated the responses to cold reversibly. Finally, the percentage of cold-sensitive neurons in TRPA1 knock-out mice was strongly reduced. The major role of TRPA1 in nodose neurons is in marked contrast with the results obtained in TG and DRG cold-sensitive sensory neurons, in which TRPM8 appears to be the principal although not the sole transduction mechanism for sensing cold (Bautista et al., 2007; Colburn et al., 2007; Dhaka et al., 2007). Knock-out strains for TRPA1 showed no major defects in cutaneous cold sensing (Bautista et al., 2006; Kwan et al., 2006; Colburn et al., 2007). It is important to point out that these studies explored only somatic sensibility to temperature and are not incompatible with a major role of TRPA1 in visceral cold sensing as suggested by our study. Still, given that TRPA1 is also strongly expressed in trigeminal and dorsal root ganglia, it is rather puzzling the lack of a cold-sensing deficit in experiments on somatosensory neurons of TRPA1(-/-) mice. For example, in the work of Bautista et al. (2006), the percentage of trigeminal CS neurons was not altered in TRPA1(-/-) animals. Furthermore, no correlation was found between cold sensitivity and response to CM, a specific TRPA1 agonist. It should be pointed out that a recent study has found a strong correlation between sensitivity to TRPA1 agonists and sensitivity to deep cooling in mice DRG (Sawada et al., 2007). The possibility that cold responses in the nodose may be caused by a novel TRPA1like channel with similar pharmacological properties to TRPA1 appears incompatible with the major reduction in cold sensitivity we observed in TRPA1(-/-) animals. (1) It is possible that cold responses may be caused by a different splice variant of TRPA1 expressed exclusively in the nodose. (2) Cold sensitivity of TRPA1 may depend on posttranslational modifications of the protein that are cell specific. (3) Cold sensitivity of nodose neurons may depend on an indirect activation mechanism of TRPA1. We find this last possibility attractive, especially in light of the lack of intrinsic cold sensitivity of TRPA1 channels (Zurborg et al., 2007) (but see Sawada et al., 2007). Thus, it is possible that nodose TRPA1 channels are more sensitive to activation by calcium ions compared with somatic sensory neurons (Doerner et al., 2007; Zurborg et al., 2007). Future behavioral studies in
TRPA1(-/-) mice will be important to establish the functional role of TRPA1 in cold transduction in different visceral organs.

\section{Functional role of visceral cold-sensitive neurons}

Pain is the dominant sensation elicited by stimulation of most internal organs, and is thought to arise mainly from their innervation by nociceptive sensory afferents that enter the spinal cord (Cervero and Laird, 2004). However, there is ample experimental evidence of vagal receptors responding to intense mechanical stimulation, irritant chemicals, or algogenic substances (Ness and Gebhart, 1990; Kang et al., 2004; Yu et al., 2005; Bielefeldt et al., 2006; Hisata et al., 2006), which also become sensitized by heat and noxious chemical stimuli (Kang et al., 2004). These receptors are thought to be involved in multiple autonomic reflexes (Paintal, 1973). Sensitivity to cold of vagal polymodal nociceptor fibers has not been explored in detail. However, neurons responding to flow of cold air through the larynx have been recorded in cats and dogs (Jammes et al., 1987; Sant'Ambrogio et al., 1988). More recently, Lennerz et al. (2007) identified superior laryngeal nerve fibers that innervate the esophagus of the rat and respond to mechanical stimulation and cold in a range between 30 and $15^{\circ} \mathrm{C}$, and often also to irritant chemicals and heat. These fibers represent $\sim 40 \%$ of the mechanosensitive vagal fibers of the esophagus and may correspond to the axons of cold-sensitive TRPA1 nodose ganglion neurons identified in our study. We also found a small number of nodose cold-sensitive but TRPA1insensitive neurons that present pharmacological properties closer to those of low-threshold cold-sensitive neurons of somatosensory ganglia; these vagal neurons probably express TRPM 8 and could be the origin of the low-threshold-specific cold-receptor fibers incidentally reported in the vagus nerve (El Ouazzani and Mei, 1982). Still, the nociceptive-like phenotype of most CS vagal sensory neurons suggest that they serve predominantly a nociceptive function.

Although conscious, sensory-discriminative aspects of visceral sensation appear to be performed mainly by spinal neurons (Ness and Gebhart, 1990), there is evidence that sensory information provided by vagal neurons makes a distinct contribution to disease-related alterations in visceral sensation such as nausea and emesis and in the emotional-affective aspects of abdominal nociception (Zagon, 2001; Holzer, 2007). Local stimulation of vagal cold-sensitive fibers innervating the stomach in dogs inhibit gastric motility and increase ventilation (El Ouazzani and Mei, 1982). Cooling the abdominal cavity also triggers behavioral and metabolic thermoregulatory responses (Baldwin, 1975). Moreover, cold exposure in rats induces c-fos expression in the nucleus of the solitary tract, the first relay of vagal sensory information within the brainstem (Miyata et al., 1995). From the nucleus of the solitary tract, vagal information projects massively to the parabrachial nucleus, a region which also receives information from somatic cold-sensory fibers and has a role in thermoregulation (Nakamura and Morrison, 2008). Thus, it is possible that cold-sensitive vagal neurons play a role in eliciting non-noxious thermoregulatory reflexes.

Part of the nodose ganglion CS neurons that we studied innervated the larynx through the superior laryngeal nerve. This nerve contains cold-sensitive afferents with broad thermal thresholds that reach the nociceptive range (Jammes et al., 1987) and may act as sensors for air flow (Sant'Ambrogio et al., 1988). The general properties and pharmacology of superior laryngeal nerve neurons were similar to the rest of nodose CS neurons. Breathing cold air can induce potent protective respiratory reflexes, including bronchospasm and cough (Coleridge and Coleridge, 1984; 
Berk et al., 1987). A recent study on single nodose neurons innervating the bronchia found that they express TRPA1, but not TRPM8, and respond to cinnamaldehyde (Nassenstein et al., 2008). Together with our findings, these data suggest a critical role of a TRPA1 channels in cold-evoked bronchopulmonary reflexes.

In summary, our study identified TRPA1 as the principal molecular element for transduction of cold temperatures by visceral neurons in the nodose ganglion, in striking contrast with the main role of TRPM8 channels in cold sensing by somatic neurons. This difference has obvious implications for the design and development of drugs specifically targeting populations of visceral nociceptors.

\section{References}

Babes A, Zorzon D, Reid G (2004) Two populations of cold-sensitive neurons in rat dorsal root ganglia and their modulation by nerve growth factor. Eur J Neurosci 20:2276-2282.

Baldwin BA (1975) The effects of intra-ruminal loading with cold water on thermoregulatory behaviour in sheep. J Physiol 249:139-152.

Bandell M, Story GM, Hwang SW, Viswanath V, Eid SR, Petrus MJ, Earley TJ, Patapoutian A (2004) Noxious cold ion channel TRPA1 is activated by pungent compounds and bradykinin. Neuron 41:849-857.

Bautista DM, Movahed P, Hinman A, Axelsson HE, Sterner O, Högestätt ED, Julius D, Jordt SE, Zygmunt PM (2005) Pungent products from garlic activate the sensory ion channel TRPA1. Proc Natl Acad Sci U S A 102:12248-12252.

Bautista DM, Jordt SE, Nikai T, Tsuruda PR, Read AJ, Poblete J, Yamoah EN, Basbaum AI, Julius D (2006) TRPA1 mediates the inflammatory actions of environmental irritants and proalgesic agents. Cell 124:1269-1282.

Bautista DM, Siemens J, Glazer JM, Tsuruda PR, Basbaum AI, Stucky CL, Jordt SE, Julius D (2007) The menthol receptor TRPM8 is the principal detector of environmental cold. Nature 448:204-208.

Behrendt HJ, Germann T, Gillen C, Hatt H, Jostock R (2004) Characterization of the mouse cold-menthol receptor TRPM8 and vanilloid receptor type-1 VR1 using a fluorometric imaging plate reader (FLIPR) assay. Br J Pharmacol 141:737-745

Berk JL, Lenner KA, McFadden ER Jr (1987) Cold-induced bronchoconstriction: role of cutaneous reflexes vs. direct airway effects. J Appl Physiol 63:659-664.

Bielefeldt K, Zhong F, Koerber HR, Davis BM (2006) Phenotypic characterization of gastric sensory neurons in mice. Am J Physiol Gastrointest Liver Physiol 291:G987-G997.

Brauchi S, Orio P, Latorre R (2004) Clues to understanding cold sensation: thermodynamics and electrophysiological analysis of the cold receptor TRPM8. Proc Natl Acad Sci U S A 101:15494-15499.

Carr MJ, Undem BJ (2003) Bronchopulmonary afferent nerves. Respirology 8:291-301.

Caterina MJ, Schumacher MA, Tominaga M, Rosen TA, Levine JD, Julius D (1997) The capsaicin receptor: a heat-activated ion channel in the pain pathway. Nature 389:816-824.

Cervero F (1994) Sensory innervation of the viscera: peripheral basis of visceral pain. Physiol Rev 74:95-138.

Cervero F, Laird JM (2004) Understanding the signaling and transmission of visceral nociceptive events. J Neurobiol 61:45-54.

Chuang HH, Neuhausser WM, Julius D (2004) The super-cooling agent icilin reveals a mechanism of coincidence detection by a temperaturesensitive TRP channel. Neuron 43:859-869.

Colburn RW, Lubin ML, Stone DJ Jr, Wang Y, Lawrence D, D'Andrea MR, Brandt MR, Liu Y, Flores CM, Qin N (2007) Attenuated cold sensitivity in TRPM8 null mice. Neuron 54:379-386.

Coleridge JC, Coleridge HM (1984) Afferent vagal C fibre innervation of the lungs and airways and its functional significance. Rev Physiol Biochem Pharmacol 99:1-110.

Dhaka A, Murray AN, Mathur J, Earley TJ, Petrus MJ, Patapoutian A (2007) TRPM8 is required for cold sensation in mice. Neuron 54:371-378.

Doerner JF, Gisselmann G, Hatt H, Wetzel CH (2007) Transient receptor potential channel A1 is directly gated by calcium ions. J Biol Chem 282: $13180-13189$

El Ouazzani T, Mei N (1982) Electrophysiologic properties and role of the vagal thermoreceptors of lower esophagus and stomach of cat. Gastroenterology 83:995-1001.

García-Añoveros J, Nagata K (2007) TRPA1. Handb Exp Pharmacol $347-362$.

Grynkiewicz G, Poenie M, Tsien RY (1985) A new generation of $\mathrm{Ca}^{2+}$ indicators with greatly improved fluorescence properties. J Biol Chem 260:3440-3450.

Higashi H (1986) Pharmacological aspects of visceral sensory receptors. Prog Brain Res 67:149-162.

Hisata Y, Zeredo JL, Eishi K, Toda K (2006) Cardiac nociceptors innervated by vagal afferents in rats. Auton Neurosci 126-127:174-178.

Hjerling-Leffler J, Alqatari M, Ernfors P, Koltzenburg M (2007) Emergence of functional sensory subtypes as defined by transient receptor potential channel expression. J Neurosci 27:2435-2443.

Holzer P (2007) Role of visceral afferent neurons in mucosal inflammation and defense. Curr Opin Pharmacol 7:563-569.

Inesi G, Hua S, Xu C, Ma H, Seth M, Prasad AM, Sumbilla C (2005) Studies of $\mathrm{Ca}^{2+}$ ATPase (SERCA) inhibition. J Bioenerg Biomembr 37:365-368.

Jammes Y, Barthelemy P, Fornaris M, Grimaud C (1986) Cold-induced bronchospasm in normal and sensitized rabbits. Respir Physiol 63:347-360.

Jammes Y, Nail B, Mei N, Grimaud C (1987) Laryngeal afferents activated by phenyldiguanide and their response to cold air or helium-oxygen. Respir Physiol 67:379-389.

Kang YM, Bielefeldt K, Gebhart GF (2004) Sensitization of mechanosensitive gastric vagal afferent fibers in the rat by thermal and chemical stimuli and gastric ulcers. J Neurophysiol 91:1981-1989.

Karashima Y, Damann N, Prenen J, Talavera K, Segal A, Voets T, Nilius B (2007) Bimodal action of menthol on the transient receptor potential channel TRPA1. J Neurosci 27:9874-9884.

Kwan KY, Allchorne AJ, Vollrath MA, Christensen AP, Zhang DS, Woolf CJ, Corey DP (2006) TRPA1 contributes to cold, mechanical, and chemical nociception but is not essential for hair-cell transduction. Neuron 50:277-289.

Lee BP, Morton RF, Lee LY (1992) Acute effects of acrolein on breathing: role of vagal bronchopulmonary afferents. J Appl Physiol 72:1050-1056.

Lee LY, Pisarri TE (2001) Afferent properties and reflex functions of bronchopulmonary C-fibers. Respir Physiol 125:47-65.

Lennerz JK, Dentsch C, Bernardini N, Hummel T, Neuhuber WL, Reeh PW (2007) Electrophysiological characterization of vagal afferents relevant to mucosal nociception in the rat upper oesophagus. J Physiol 582:229-242.

Li BY, Schild JH (2002) Patch clamp electrophysiology in nodose ganglia of adult rat. J Neurosci Methods 115:157-167.

Macpherson LJ, Geierstanger BH, Viswanath V, Bandell M, Eid SR, Hwang S, Patapoutian A (2005) The pungency of garlic: activation of TRPAl and TRPV1 in response to allicin. Curr Biol 15:929-934.

Macpherson LJ, Hwang SW, Miyamoto T, Dubin AE, Patapoutian A, Story GM (2006) More than cool: promiscuous relationships of menthol and other sensory compounds. Mol Cell Neurosci 32:335-343.

Madrid R, Donovan-Rodríguez T, Meseguer V, Acosta MC, Belmonte C, Viana F (2006) Contribution of TRPM8 channels to cold transduction in primary sensory neurons and peripheral nerve terminals. J Neurosci 26:12512-12525.

Malkia A, Madrid R, Meseguer V, de la PE, Valero M, Belmonte C, Viana F (2007) Bidirectional shifts of TRPM8 channel gating by temperature and chemical agents modulate the cold sensitivity of mammalian thermoreceptors. J Physiol 581:155-174.

McKemy DD (2005) How cold is it? TRPM8 and TRPA1 in the molecular logic of cold sensation. Mol Pain 1:16.

McKemy DD, Neuhausser WM, Julius D (2002) Identification of a cold receptor reveals a general role for TRP channels in thermosensation. $\mathrm{Na}-$ ture 416:52-58.

McNamara CR, Mandel-Brehm J, Bautista DM, Siemens J, Deranian KL, Zhao M, Hayward NJ, Chong JA, Julius D, Moran MM, Fanger CM (2007) TRPA1 mediates formalin-induced pain. Proc Natl Acad Sci U S A 104:13525-13530.

Mei N, Condamin M, Boyer A (1980) The composition of the vagus nerve of the cat. Cell Tissue Res 209:423-431.

Miyata S, Ishiyama M, Shido O, Nakashima T, Shibata M, Kiyohara T (1995) Central mechanism of neural activation with cold acclimation of rats using Fos immunohistochemistry. Neurosci Res 22:209-218. 
Moqrich A, Hwang SW, Earley TJ, Petrus MJ, Murray AN, Spencer KS, Andahazy M, Story GM, Patapoutian A (2005) Impaired thermosensation in mice lacking TRPV3, a heat and camphor sensor in the skin. Science 307:1468-1472.

Nagata K, Duggan A, Kumar G, García-Añoveros J (2005) Nociceptor and hair cell transducer properties of TRPA1, a channel for pain and hearing. J Neurosci 25:4052-4061.

Nakamura K, Morrison SF (2008) A thermosensory pathway that controls body temperature. Nat Neurosci 11:62-71.

Nassenstein C, Kwong K, Taylor-Clark T, Kollarik M, Macglashan DM, Braun A, Undem BJ (2008) Expression and function of the ion channel TRPA1 in vagal afferent nerves innervating mouse lungs. J Physiol 586:1595-1604.

Ness TJ, Gebhart GF (1990) Visceral pain: a review of experimental studies. Pain 41:167-234.

Ni D, Gu Q, Hu HZ, Gao N, Zhu MX, Lee LY (2006) Thermal sensitivity of isolated vagal pulmonary sensory neurons: role of transient receptor potential vanilloid receptors. Am J Physiol Regul Integr Comp Physiol 291:R541-R550.

Orani GP, Anderson JW, Sant'Ambrogio G, Sant'Ambrogio FB (1991) Upper airway cooling and l-menthol reduce ventilation in the guinea pig. J Appl Physiol 70:2080-2086.

Paintal AS (1973) Vagal sensory receptors and their reflex effects. Physiol Rev 53:159-227.

Patapoutian A, Peier AM, Story GM, Viswanath V (2003) ThermoTRP channels and beyond: mechanisms of temperature sensation. Nat Rev Neurosci 4:529-539.

Peeters PJ, Aerssens J, De Hoogt R, Stanisz A, Göhlmann HW, Hillsley K, Meulemans A, Grundy D, Stead RH, Coulie B (2006) Molecular profiling of murine sensory neurons in the nodose and dorsal root ganglia labeled from the peritoneal cavity. Physiol Genomics 24:252-263.

Peier AM, Moqrich A, Hergarden AC, Reeve AJ, Andersson DA, Story GM, Earley TJ, Dragoni I, McIntyre P, Bevan S, Patapoutian A (2002) A TRP channel that senses cold stimuli and menthol. Cell 108:705-715.

Reid G (2005) ThermoTRP channels and cold sensing: what are they really up to? Pflugers Arch 451:250-263.

Reid G, Babes A, Pluteanu F (2002) A cold- and menthol-activated current in rat dorsal root ganglion neurones: properties and role in cold transduction. J Physiol 545:595-614.

Sant'Ambrogio G, Mathew OP, Sant'Ambrogio FB (1988) Characteristics of laryngeal cold receptors. Respir Physiol 71:287-297.
Sawada Y, Hosokawa H, Hori A, Matsumura K, Kobayashi S (2007) Cold sensitivity of recombinant TRPA1 channels. Brain Res 1160:39-46.

Steiner AA, Turek VF, Almeida MC, Burmeister JJ, Oliveira DL, Roberts JL, Bannon AW, Norman MH, Louis JC, Treanor JJ, Gavva NR, Romanovsky AA (2007) Nonthermal activation of transient receptor potential vanilloid-1 channels in abdominal viscera tonically inhibits autonomic cold-defense effectors. J Neurosci 27:7459-7468.

Story GM, Peier AM, Reeve AJ, Eid SR, Mosbacher J, Hricik TR, Earley TJ, Hergarden AC, Andersson DA, Hwang SW, McIntyre P, Jegla T, Bevan S, Patapoutian A (2003) ANKTM1, a TRP-like channel expressed in nociceptive neurons, is activated by cold temperatures. Cell 112:819-829.

Thut PD, Wrigley D, Gold MS (2003) Cold transduction in rat trigeminal ganglia neurons in vitro. Neuroscience 119:1071-1083.

Valenzano KJ, Grant ER, Wu G, Hachicha M, Schmid L, Tafesse L, Sun Q, Rotshteyn Y, Francis J, Limberis J, Malik S, Whittemore ER, Hodges D (2003) N-(4-tertiarybutylphenyl)-4-(3-chloropyridin-2-

yl)tetrahydropyrazine -1(2H)-carbox-amide (BCTC), a novel, orally effective vanilloid receptor 1 antagonist with analgesic properties: I. in vitro characterization and pharmacokinetic properties. J Pharmacol Exp Ther 306:377-386.

Viana F, de la Peña E, Belmonte C (2002) Specificity of cold thermotransduction is determined by differential ionic channel expression. Nat Neurosci 5:254-260.

Voets T, Droogmans G, Wissenbach U, Janssens A, Flockerzi V, Nilius B (2004) The principle of temperature-dependent gating in cold- and heatsensitive TRP channels. Nature 430:748-754.

$\mathrm{Xu}$ H, Blair NT, Clapham DE (2005) Camphor activates and strongly desensitizes the transient receptor potential vanilloid subtype 1 channel in a vanilloid-independent mechanism. J Neurosci 25:8924-8937.

Yu S, Undem BJ, Kollarik M (2005) Vagal afferent nerves with nociceptive properties in guinea-pig oesophagus. J Physiol 563:831-842.

Zagon A (2001) Does the vagus nerve mediate the sixth sense? Trends Neurosci 24:671-673.

Zhang L, Jones S, Brody K, Costa M, Brookes SJ (2004) Thermosensitive transient receptor potential channels in vagal afferent neurons of the mouse. Am J Physiol Gastrointest Liver Physiol 286:G983-G991.

Zurborg S, Yurgionas B, Jira JA, Caspani O, Heppenstall PA (2007) Direct activation of the ion channel TRPA1 by $\mathrm{Ca}(2+)$. Nat Neurosci 10:277-279. 